\title{
The Origins of Soviet Ethnic Cleansing
}

\section{Citation}

Martin, Terry. 1998. The origins of Soviet ethnic cleansing. Journal of Modern History 70, no. 4: 813-861.

\section{Published Version}

http://dx.doi.org/10.1086/235168

\section{Permanent link}

http://nrs.harvard.edu/urn-3:HUL.InstRepos:3229636

\section{Terms of Use}

This article was downloaded from Harvard University's DASH repository, and is made available under the terms and conditions applicable to Other Posted Material, as set forth at http:// nrs.harvard.edu/urn-3:HUL.InstRepos:dash.current.terms-of-use\#LAA

\section{Share Your Story}

The Harvard community has made this article openly available.

Please share how this access benefits you. Submit a story.

Accessibility 


\title{
The Origins of Soviet Ethnic Cleansing*
}

\author{
Terry Martin \\ Harvard University
}

In February 1937, a young English adventurer, Fitzroy Maclean, arrived in Moscow to take up the position of third secretary at the British Embassy. Maclean harbored a secret ambition: "I was going, if it was humanly possible, to the Caucasus and Central Asia, to Tashkent, Bokhara and Samarkand." However, foreigners were then forbidden access to central Asia. So Maclean instead boarded a train for Baku, hoping that from there he could cross the Caspian Sea and reach central Asia. In Baku, he illegally boarded a steamer to Lenkoran, a Caspian port near the border of Azerbaijan and Persia. There he found a hotel room. The next morning he was awakened early by a procession of trucks, which continued the entire day, "driving headlong through the town on the way to the port, each filled with depressed-looking Turko-Tartar peasants under the escort of NKVD frontier troops with fixed bayonets."2 At the port, the peasants were being loaded onto ships for deportation to central Asia.

The people of Lenkoran gathered to watch the deportation and speculate on its cause. Maclean favored the explanation of an elderly Russian, who said that "the arrests had been decreed from Moscow and merely formed part of the deliberate policy of the Soviet government, who believed in transplanting portions of the population from place to place as and when it suited them. The place of those now being deported would probably be taken by other peasants from central Asia." This, he said, had happened before. It was, he remarked somewhat cryptically, "a measure of precaution." ${ }^{3}$ Another local approached

* Research support for this article was provided by the Social Sciences and Humanities Research Council (SSHRC) of Canada, the International Research and Exchanges Board (IREX), and the MacArthur Foundation's CASPIC program. Drafts of the article were presented at the University of Chicago's Historical Sociology and Comparative Politics Workshop and at Andrea Graziosi's seminar, "New Approaches to the History of the 1930s," in Paris. I would like to thank the participants in those conferences for their comments, as well as Sheila Fitzpatrick, David Laitin, Norman Naimark, Gabor Rittersporn, and Yuri Slezkine.

${ }^{1}$ Fitzroy Maclean, Eastern Approaches (New York, 1949), p. 2.

${ }^{2}$ British Foreign Office: Russia Correspondence reel 7 (1937), vol. 21107, p. 213 (hereafter cited as BFORC). See also Maclean, p. 33. Maclean filed a report to the embassy after his trip. The account in his book is a shortened, but entirely consistent, version.

${ }^{3}$ BFORC reel 7, p. 214; see also Maclean, p. 34. 
Maclean and showed him a cartoon from the Soviet satirical journal Krokodil about British deportations in India. "This is exactly what happens here," he said. ${ }^{4}$

Since all the ships to central Asia were occupied with the deportation, Maclean decided to rent a horse and ride inland to explore the nearby mountains. After a few hours, he was suddenly overtaken and surrounded by secret police (NKVD) border troops: ${ }^{5}$

Before I had taken in what was happening, I found myself staring down the barrels of a pistol and half a dozen rifles. "Hands up," said the officer, and up went my hands. I took advantage of the somewhat embarrassing pause which now ensued to explain to my captor, a shifty-looking little Tartar, that I was a diplomat and could therefore not be arrested. Did he know what a diplomat was? To this he replied, his foolish face suddenly crafty, that he knew only too well and that if I went on arguing he would shoot me on the spot instead of waiting till we got home. I said that if he did the consequences would be very unpleasant for him, to which he replied that they would be even more unpleasant for me.

Maclean escaped unscathed, but with a warning that the NKVD "had to be careful so near the frontier." 6

In September 1937, Maclean made a second attempt to reach Soviet Central Asia. This time he took the Trans-Siberian railway as far as Novosibirsk, where he defied Soviet law by boarding a train heading south toward Barnaul. Remarkably, just before reaching Barnaul, Maclean witnessed yet another largescale ethnic deportation: ${ }^{7}$

At Altaisk ... we stopped for several hours while a number of cattle trucks were hitched on to our train. These were filled with people who, at first sight, seemed to be Chinese. They turned out to be Koreans, who with their families and belongings were on their way from the Far East to Central Asia where they were being sent to work on the cotton plantations. They had no idea why they were being deported but all grinned incessantly and I gathered from the few words I could exchange with some of their number that they were pleased to have left the Far Eastern territory where conditions were terrible and to be going to Central Asia of which they had evidently been given enthusiastic accounts. Later I heard that the Soviet authorities had quite arbitrarily removed some 200,000 Koreans to Central Asia, as likely to prove untrustworthy in the event of a war with Japan. I was witnessing yet another mass movement of population.

When I first encountered Maclean's reports in the British Foreign Office's Russia Correspondence, it struck me as an incredible coincidence that he could

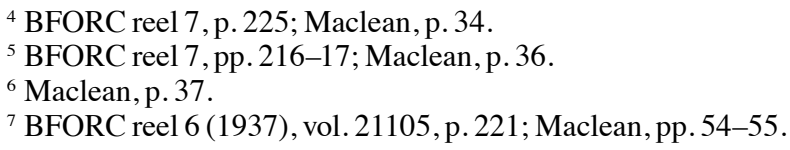


have undertaken two journeys to the Soviet periphery and on each occasion became an eyewitness to ethnic cleansing. I knew about the Korean deportation but had never heard of the Azerbaijani one. In fact, it was only after six months' work in the Moscow archives that I found an archival file confirming Maclean's account. ${ }^{8}$ I also found that Maclean's encounters were not such a coincidence after all. Between 1935 and 1938, at least nine Soviet nationalities - Poles, Germans, Finns, Estonians, Latvians, Koreans, Chinese, Kurds, Iranians - were all subjected to ethnic cleansing. ${ }^{9}$ Nor was Maclean's unpleasant encounter with the NKVD border troops unusual. He had strayed into what was known as "the forbidden border zone," a huge region running dozens of kilometers deep along the entire Soviet border. Had he been a Soviet citizen, Maclean would have gotten a one- to three-year prison term. ${ }^{10}$ Soviet ethnic cleansing began from these forbidden border zones. Finally, I found that Maclean's old Russian was on the right track. Peasants deported from the border regions were routinely replaced with demobilized Red Army soldiers.

It might seem initially that the phenomenon of Soviet ethnic cleansing requires little explanation. After all, ethnic cleansing has been a regrettably common feature of the twentieth-century landscape. The nationalist project of making state borders coincide with ethnic borders would seem to imply either assimilation, segregation, or ethnic cleansing. ${ }^{11}$ The Soviet Union was one of

\footnotetext{
${ }^{8}$ Gosudarstvennyi Arkhiv Rossiiskoi Federatsii (hereafter GARF) 5446/20a/493 (1937).

${ }^{9}$ The standard works on Soviet ethnic cleansing briefly mentioned the 1937 Korean deportation. Aleksandr M. Nekrich, The Punished Peoples: The Deportation and Fate of Soviet Minorities at the End of the Second World War (New York, 1978), pp. 98-99; Robert Conquest, The Nation Killers: The Soviet Deportation of Nationalities (London, 1977), p. 77. The Finnish deportations are mentioned in Nikolai K. Deker and Andrei Lebed, eds., Genocide in the USSR (Munich, 1958), pp. 56-57, as well as in the excellent article by Ian M. Matley, "The Dispersal of the Ingrian Finns," Slavic Review 38 (March 1979): 1-16. In recent years, N. F. Bugai has published numerous document collections on the pre-World War II deportations. His findings are summed up in N. F. Bugai, L. Beriia-I. Stalinu: "Soglasno vashemu ukazaniiu" (Moscow, 1995). See also Mikolaj Iwanov, Pierwszy narod ukarany: Polacy w zwiazku radzieckim, 1921-1939 (Warsaw, 1991); Jean-Jacques Marie, Les peuples deportes d'union sovietique (Paris, 1995), pp. 21-33; Michael Gelb, "The Western Finnic Minorities and the Origins of the Stalinist Nationalities Deportations," Nationalities Papers 24 (June 1996): 237-68, and "An Early Soviet Ethnic Deportation: The Far-Eastern Koreans," Russian Review 54 (July 1995): 389-412. Amir Weiner, "Excising Evil: The Soviet Quest for Purity and the Eradication of the Nationalist Movement in the Vinnytsia Region," in An Empire of Nations: The Soviet State and Its Peoples in the Age of Lenin and Stalin, ed. Ronald Grigor Suny and Terry Martin, in press.

${ }^{10}$ Sobranie zakonov i rasporiazhenii SSSR (05.09.35): 45/377.

${ }^{11}$ For a good theoretical account, see Ernest Gellner, Nations and Nationalism (Ithaca, N.Y., 1983). For the specific case of diaspora nationalities, see John Armstrong, "Mobi-
} 
history's most violent and repressive regimes. It engaged in mass deportations of putative class enemies. Given these facts, ethnic cleansing might seem grimly inevitable. However, the Soviet Union was not a nation-state, nor was its leadership ever committed to turning it into a nation-state. ${ }^{12}$ No attempt was made to forge a new Soviet nationality, nor to forcibly assimilate the nonRussian population. Quite the contrary. In the early Soviet period, even voluntary assimilation was actively discouraged. The Soviet regime devoted considerable resources to the promotion of the national self-consciousness of its non-Russian populations. Each Soviet nation, no matter how small, was granted its own national territory, national schools, and national elites. Dozens of written national languages were created for ethnic groups that lacked them. This commitment to ethnic proliferation would seem to have made the Soviet Union a highly unlikely site for the emergence of ethnic cleansing. ${ }^{13}$

Indeed, the simultaneous pursuit of nation building and nation destroying in the Stalinist period remains a paradox in need of explanation. Earlier studies of the Soviet nationalities policy tended to emphasize a shift from a moderate policy of national concessions in the 1920s to a repressive policy featuring ethnic deportations, national terror, and russification..$^{14}$ More recent studies have instead focused on the impressive continuity in the Soviet commitment to nation building throughout the entire Stalinist period and beyond.${ }^{15}$ However, neither approach gives a satisfactory explanation of the most striking paradox of the last two decades of Stalin's rule: the simultaneous pursuit of nation building and nation destroying. My discussion of the origins of Soviet ethnic cleansing will attempt to address this paradox by showing how, under certain conditions, the same principles that informed Soviet nation building could and did lead to ethnic cleansing and ethnic terror against a limited set of stigmatized

lized and Proletarian Diasporas," American Political Science Review 70 (1976): 393-408.

${ }^{12}$ On this point, see Yuri Slezkine, "The USSR as a Communal Apartment, or How a Socialist State Promoted Ethnic Particularism," Slavic Review 53 (Summer 1994): 414-52.

${ }^{13}$ For a detailed study of the Soviet nationalities policy and its consequences, see Terry Martin, "An Affirmative Action Empire: Ethnicity and the Soviet State, 1923-1938" (Ph.D. diss., University of Chicago, 1996).

${ }^{14}$ For representative works, see Walter Kolarz, Russia and Her Colonies (London, 1953); Conquest, The Nation Killers; Alexandre A. Bennigsen and Enders S. Wimbush, Muslim National Communism in the Soviet Union: A Revolutionary Strategy for the Colonial World (Chicago, 1979).

${ }^{15}$ The most influential works are Ronald Grigor Suny, The Revenge of the Past: Nationalism, Revolution, and the Collapse of the Soviet Union (Stanford, Calif., 1993); Slezkine; Rogers Brubaker, Nationalism Reframed: Nationhood and the National Question in the New Europe (Cambridge, 1996), pp. 23-54. 
nationalities, while leaving nation-building policies in place for the majority of nonstigmatized nationalities.

\section{Ethnic Cleansing in the Eurasian Borderlands, 1912-53}

Before attempting to explain this Stalinist paradox, I will briefly situate Soviet actions in a contemporary regional context in order to highlight both what was typical and what was distinctive in Soviet ethnic cleansing. I will also specify precisely what I mean by "ethnic cleansing." This term, of course, emerged during the recent conflict in the former Yugoslavia, but the practice itself is considerably older and has been especially common in the twentieth century. ${ }^{16}$ For that reason, both scholars and popular writers have now extended the term "ethnic cleansing" to other historical and contemporary instances of the forcible removal of an ethnically defined population from a given territory. ${ }^{17} \mathrm{Of}$ course, as any Soviet historian is well aware, populations defined by class, religion, political reliability, race, and many other categories have also been subjected to forcible relocation. However, ethnic cleansing has been by far the most widespread practice in the twentieth century. Indeed, a goal of my article is to explain the unexpected Soviet transition from class-based deportations to ethnic cleansing.

A comprehensive history of ethnic cleansing has not yet been written. ${ }^{18}$ In order to contextualize Soviet behavior - to illustrate both the ubiquity and the variety of contemporary ethnic cleansing - I will provide a very brief and incomplete survey of ethnic cleansing from 1912 to 1953 in the Eurasian border-

${ }^{16}$ For a good comparative discussion of the origins of the term "ethnic cleansing" and the politics surrounding it, see Robert M. Hayden, "Schindler's Fate: Genocide, Ethnic Cleansing, and Population Transfers," Slavic Review 55 (Winter 1996): 727-48; see also Akbar S. Ahmed, “'Ethnic Cleansing': A Metaphor for Our Time?” Ethnic and Racial Studies 18, no. 1 (1995): 1-25.

${ }^{17}$ For example, a title search of the OCLC WorldCat database on March 26, 1998, found twenty-seven books with "ethnic cleansing" in the title, all published after 1992. Eleven books deal with the wars in the former Yugoslavia and sixteen books with other historical or contemporary instances of the forcible removal of an ethnically defined population from a given territory. The wording of this definition is mine. It differs slightly from the definition of ethnic cleansing formulated by an official United Nations commission as "rendering an area ethnically homogeneous by using force or intimidation to remove from a given area persons of another ethnic or religious group" (cited in Hayden, p. 732). In fact, ethnic cleansing rarely aims at complete ethnic homogeneity. The common practice is the removal of one or more stigmatized ethnic groups.

${ }^{18}$ Brief and somewhat eclectic surveys are provided in Andrew Bell-Fialkoff, Ethnic Cleansing (New York, 1996), pp. 7-50; Milica Zarkovic Bookman, The Demographic Struggle for Power: The Political Economy of Demographic Engineering in the Modern World (London, 1997), pp. 121-46. 
lands: that is, the L-shaped swath of territory extending southward from Leningrad through the Balkans, and then eastward across southern Ukraine and Turkey into the Caucasus region. Although ethnic cleansing began in this region long before 1912, the two Balkan wars of 1912-13 witnessed a dramatic extension of the practice, as each of the warring states engaged in purposeful expulsions and massacres of rival minorities in order to further their postwar demographic claims to conquered territory. ${ }^{19}$ The conclusion of these wars witnessed the world's first internationally sanctioned "population exchange" in the form of a 1913 Turko-Bulgarian convention agreeing to the exchange of 48,570 Turks and 46,764 Bulgarians from the two countries' respective fifteenkilometer frontier zones. As would frequently be the case with future analogous agreements, the populations concerned had already been expelled and the treaty served only to formalize the expulsions and regulate property claims. ${ }^{20}$

World War I led to a dramatic escalation in the practice of ethnic cleansing. In 1915, the Ottoman Empire not only deported its entire Armenian population from the north-east frontier but also subjected the deported Armenians to genocidal massacres, starvation, and death from exposure. ${ }^{21}$ At the same time, the Russian army deported approximately 800,000 of their own ethnically Jewish and ethnically German citizens away from the front and other regions under military rule. ${ }^{22}$ In addition, the Russian government passed and began to imple-

${ }^{19}$ On ethnic cleansing in the nineteenth century, see Justin McCarthy, Death and Exile: The Ethnic Cleansing of Ottoman Muslims (Princeton, N.J., 1993); Alan W. Fisher, "Emigration of Muslims from the Russian Empire in the Years after the Crimean War," Jahrbucher fur Geschichte Osteuropas 35, no. 3 (1987): 356-71. On the Balkan wars, see George F. Kennan, The Other Balkan Wars: A 1913 Carnegie Endowment Inquiry in Retrospect with a New Introduction and Reflections on the Present Conflict (Washington, D.C., 1993).

${ }^{20}$ Stephen P. Ladas, The Exchange of Minorities: Bulgaria, Greece and Turkey (New York, 1932), pp. 18-20. In 1914, in response to Ottoman threats to deport their Greek minority away from the Aegean coast, Greece signed an agreement with the Ottoman Empire for an exchange of some of their respective Greek and Turkish minority populations. The outbreak of World War I prevented the implementation of this agreement. Ladas, pp. 20-23.

${ }^{21}$ Vahakn N. Dadrian, The History of the Armenian Genocide: Ethnic Conflict from the Balkans to Anatolia to the Caucasus (Oxford, 1995).

${ }^{22}$ The standard work on these deportations has been written by Eric Lohr, "Internal Enemy Politics and the Nationalization of Imperial Space: Enemy Aliens within the Russian Empire during World War I" (Ph.D. diss., Harvard University, forthcoming), chaps. 2-3. I thank the author for letting me read and cite his manuscript. For published accounts, see Ingeborg Fleischhauer, Die Deutschen im Zarenreich. Zwei Jahrhunderte deutsch-russische Kulturgemeinschaft (Stuttgart, 1986), pp. 507-11; Joshua Sanborn, "Drafting the Nation: Military Conscription and the Formation of a Modern Polity in Tsarist and Soviet Russia, 1905-1925" (Ph.D. diss., University of Chicago, 1998), chap. 5; "Dokumenty o presledovanii evreev," Arkhiv russkoi revoliutsii, tom 19 (Berlin, 1928), pp. 245-84. For a fascinating discussion of the origins of various "cleansing" operations 
ment legislation liquidating German landholdings (i.e., land owned by Russian citizens of ethnic German descent) in a 100- to 150-kilometer strip along the entire L-shaped curve of the Russian border from the Baltic to the Caspian. ${ }^{23}$ Germany had already begun a limited expropriation of Polish landholdings in its eastern border regions in $1908 .^{24}$ During the war, plans were drawn up to annex Russian territory and deport this Polish population eastward, but Germany's defeat prevented their execution. ${ }^{25}$ Finally, the collapse of the 1919 Greek invasion of Turkey in September 1922 was accompanied by the expulsion of almost a million Greeks from Turkey's Aegean coast. The 1923 Treaty of Lausanne formalized this expulsion and likewise authorized an involuntary exchange of Turkey's remaining Greek population and Greece's remaining Turkish minority. ${ }^{26}$

With the exception of the Soviet ethnic deportations described in this article, there were no further overt episodes of ethnic cleansing until the outbreak of World War II, which initiated the largest wave of ethnic cleansing in European history. The Nazi state had grandiose plans to ethnically cleanse large regions of eastern Europe, particularly Poland, for resettlement by ethnic Germans plans that were partially realized prior to Germany's defeat ${ }^{27}$ The genocide of 6 million European Jews was a unique event in both scope and kind, but it was also the most extreme manifestation of the contemporary practice of ethnic cleansing. Germany's allies and satellite states were allowed to undertake their

in Tsarist Russia and the revolutionary period, see Peter Holquist, “'To Remove' and 'To Exterminate Totally': Population Statistics and Population Politics in Late Imperial and Soviet Russia," forthcoming in Suny and Martin, eds. (n. 9 above).

${ }^{23}$ K. E. Lindemann, Prekrashchenie zemlevladeniia $i$ zemlepolzovaniia poseliansobstvennikov (Moscow, 1917). The expropriations technically targeted German "colonists" or poselian-sobstvennikov, an ethno-soslovie category that exempted Baltic German nobles and others.

${ }^{24}$ William W. Hagen, Germans, Poles, and Jews: The Nationality Conflict in the Prussian East, 1772-1914 (Chicago, 1980), pp. 188-207.

${ }^{25}$ Ibid., pp. 206-7, 320-22; Immanuel Geiss, Der Polnische Grenzstreifen, 1914 1918: Ein Beitrag zur deutschen Kriegszielpolitik im ersten Weltkrieg (Lubeck, 1960).

${ }^{26}$ Ladas, pp. 335-53. The Greeks of Istanbul and Turks of western Thrace were exempted. A 1919 treaty between Greece and Bulgaria also authorized a voluntary exchange of their respective minorities, which was consummated only after coercion was employed. Ladas, pp. 27-123. The formation of new states in east central Europe in 1919 led to a series of semivoluntary pressured emigrations. See Daria Stolz, "Forced Migrations in Central European History," International Migration Review 26, no. 2 (1992): 329.

${ }^{27}$ Prior to October 1941, approximately 1.3 million Poles and Jews were deported from the western regions of Poland that were formally annexed and included in the German reich.Approximately 1.25 million Germans from eastern Europe and the Reich were then resettled in these regions. Joseph B. Schechtman, European Population Transfers, 19391945 (New York, 1946), pp.3-366. On the continuity between Imperial German and Nazi policies in this region, see Hagen, pp. 320-22. 
own ethnic cleansing projects. The Croatian Ustasha state murdered hundreds of thousands of Serbs and forced many more to flee Ustasha-controlled territory. ${ }^{28}$ Beginning in 1943, the Ukrainian Insurrectionary Army (UPA) adopted a policy of massacring and expelling the Polish population of Volhynia and Eastern Galicia. ${ }^{29}$ Bulgaria's annexation of southern Dobruja from Romania in 1940 was accompanied by the two countries' agreement to an involuntary exchange of 100,000 Romanians from this territory for 61,000 Bulgarians from northern Dobruja. ${ }^{30}$ In conquered Macedonia, Bulgaria engaged in a mass expulsion of hundreds of thousands of Greeks and Serbs. ${ }^{31}$

Germany's invasion of the Soviet Union led to a massive escalation in Soviet ethnic cleansing. The Soviet government immediately deported 1.2 million citizens of German origin from European Russia to Siberia and Central Asia. ${ }^{32}$ After the retreat of the German army in 1943-44, the Soviet state deported its entire Crimean Tatar, Kalmyk, Chechen, Ingush, Balkar, Karachai, and Meskhetian Turk populations to Central Asia on the charge of collective treason. ${ }^{33}$ In addition, from 1944 through 1953, a number of peoples - Kurds, Khemshils (Moslem Armenians), Greeks, Bulgarians, Armenians from the Black Sea region, Iranians - were deported away from the Soviet border regions in Crimea and the Transcaucasus. ${ }^{34}$ In addition, it now appears that Stalin may indeed have been planning the deportation to Siberia of the entire Soviet Jewish population in the months prior to his death in March 1953. ${ }^{35}$

Germany's defeat in 1945 triggered a massive internationally sanctioned

${ }^{28}$ Aleksa Djilas, The Contested Country: Yugoslav Unity and Communist Revolution, 1919-1953 (Cambridge, Mass., 1991), pp. 103-27.

${ }^{29}$ Tadeusz Piotrowski, Vengeance of the Swallows, pp. 23-102; Jozef Turowski, ed., Zbrodnie nacjonalistow ukrainskich dokonane na ludnosci polskiej na Wolyniu, 19391945 (Warsaw, 1990).

${ }^{30}$ Schechtman, European Population Transfers, pp. 404-14.

${ }^{31}$ Ibid.,pp. 415-24.

${ }^{32}$ Bugai, L. Beriia (n. 9 above), pp. 27-55. The remaining Finnish population in Leningrad oblast was also deported in 1941-42 (pp. 191-92).

${ }^{33}$ Ibid., pp. 56-185. For earlier accounts, see Nekrich (n. 9 above); and Conquest, The Nation Killers ( $\mathrm{n} .9$ above).

${ }^{34}$ Bugai, L. Beriia, pp. 163-250. I have included in this list only deportations based explicitly on ethnic criteria. The mass deportations from the annexed territories of Moldavia, western Ukraine and Belorussia, and the three Baltic republics overwhelmingly affected non-Russians, but the deported were targeted as class enemies or, more precisely, as "former people" (byvshie): former landlords, policemen, teachers, members of various political parties, officers, etc. (given Polish overrepresentation in these positions, they were also overrepresented in the deportations). On these deportations, see Bugai, $L$. Beriia, pp. 186-250; and Deportatsii.Zakhidni zemli Ukrainy kintsa 30-kh-pochatku 50kh rr. Dokumenty, materialy, spohady. Tom 1.1939-1945 rr. (L'viv, 1996).

${ }^{35}$ For an archivally based discussion of this question, see Gennadi Kostyrchenko, Out of the Red Shadows: Anti-Semitism in Stalin's Russia (Amherst, N.Y., 1995), pp. 248-306. 
wave of ethnic cleansing in eastern Europe. At Potsdam, the Allied powers formally authorized "the transfer to Germany of German populations, or elements thereof, remaining in Poland, Czechoslovakia and Hungary." 36 Twelve to 14 million Germans were expelled from eastern Europe, including several million who fled in response to atrocities by the Red Army and local vigilantes. ${ }^{37}$ In September 1944, the Soviet Union and the Polish Lublin Committee signed a series of agreements authorizing a putatively voluntary exchange (in practice, there was much coercion) of the Polish population lying to the east of the Curzon line and the Ukrainian, Belorussian, and Russian populations lying to the west. ${ }^{38}$ The 139,467 Polish Ukrainians not relocated by the summer of 1947 were then rounded up and deported from Poland's eastern border regions to western and northern Poland. ${ }^{39}$ After Czechoslovakia ceded CarpathoUkraine to the Soviet Union in 1945, the Soviet Union and Czechoslovakia agreed to a voluntary exchange of populations. ${ }^{40}$ In addition, the postwar years witnessed an aborted Slovak-Hungarian exchange of minorities and a semivoluntary repatriation of ethnic Turks from Bulgaria. ${ }^{41}$ The death of Stalin in 1953 marked the end of this era of mass ethnic cleansing in the Eurasian borderlands. ${ }^{42}$

This brief survey should serve to demonstrate the great variety of actions that must be included under the general category of the forcible removal of an ethnically defined population from a given territory. In order to isolate the distinctive features of Soviet ethnic cleansing, we can examine five major vari-

${ }^{36}$ Joseph B. Schechtman, Postwar Population Transfers in Europe, 1945-1955 (Philadelphia, 1962), pp. 36-37.

${ }^{37}$ Germans were also expelled, without formal authorization, from Yugoslavia and Romania. On the atrocities suffered by the German population, see Alfred-Maurice de Zayas, The German Expellees: Victims in War and Peace (New York, 1993).

${ }^{38}$ Schectman, Postwar Population Transfers, pp. 151-79; Bohdan Kordan, "Making Borders Stick: Population Transfer and Resettlement in the Trans-Curzon Territories, 1944-1949," International Migration Review 31, no. 3 (1997): 704-50. For excellent documents, see Deportatsii, pp. 294-647. Approximately 1.5 million people were relocated in the period 1944-46.

${ }^{39}$ Kordan,pp. 712-17; Eugeniusz Misilo, Akcja “Wisla.” Dokumenty (Warsaw, 1993).

${ }^{40}$ At least on the Czechoslovak side, this exchange appears to have been voluntary. Almost all of the Soviet Union's Czechs and Slovaks emigrated, while about 4,500 of Czechoslovakia's 91,000 Ukrainians/Ruthenians and Russians emigrated. Schechtman, Postwar Population Transfers, pp. 43-49.

${ }^{41}$ Ibid., pp. 129-50, 341-62.

${ }^{42}$ Ethnic cleansing, however, has been quite common in the new states of Africa and Asia. Joseph B. Schechtman, Population Transfers in Asia (New York, 1949); Jean-Marie Henckaerts, Mass Expulsion in Modern International Law and Practice (The Hague, 1995); Donald L. Horowitz, Ethnic Groups in Conflict (Berkeley, 1985), pp. 196-201. The collapse of Communism in the late 1980s, of course, triggered a resumption of ethnic cleansing in the Balkans and the Caucasus. 
ables in the practice of ethnic cleansing in general. Ethnic cleansing may involve forcible removal with no intent to murder, or it may (more frequently) be accompanied by varying degrees of intentional mass murder. ${ }^{43}$ Ethnic cleansing may be carried out by trained professionals (usually the security police) or it may involve varying degrees of mass popular mobilization. Ethnic cleansing may be partial or total. The stigmatized ethnicity may be expelled abroad (usually to their "home" nation-state) or resettled internally (usually away from sensitive frontier regions). Finally, ethnic cleansing may occur during war or peace. ${ }^{44}$ One might also note the presence or absence of several practices that often accompany ethnic cleansing, such as ethnic dilution (resettling members of trusted ethnic groups into regions dominated by stigmatized ethnic groups), ethnic consolidation (territorially concentrating dispersed ethnic groups), and forced assimilation. ${ }^{45}$

Soviet ethnic cleansing was not accompanied by overt intentional murder. However, the ethnic deportations always included many arrests that resulted in incarceration in high-mortality prison camps. Moreover, the deportations were carried out incredibly swiftly, which insured that large numbers of individuals would die of exposure, starvation, and disease both during and after the deportations, especially since the deported were placed in prison-like "special settlements." ${ }^{46}$ Finally, and most importantly, under Soviet conditions all deported ethnic groups (and other population categories) were stigmatized and therefore extremely vulnerable during periodic terror campaigns. The diaspora nationalities deported in the period between 1935 and 1938 were singled out for disproportionate arrest and mass execution during the Great Terror of 1937-38 to a degree that, as I will show, verged on the genocidal. Therefore, as with most cases of ethnic cleansing, the Soviet practice included substantial levels of intentional murder. ${ }^{47}$

${ }^{43}$ When murder itself becomes the primary goal, it is typically called genocide. On the term "genocide," see Leo Kuper, Genocide: Its Political Use in the Twentieth Century (New Haven, Conn., 1981). Ethnic cleansing is probably best understood as occupying the central part of a continuum between genocide on one end and nonviolent pressured ethnic emigration on the other end. Given this continuum, there will always be ambiguity as to when ethnic cleansing shades into genocide, or pressured emigration into forced relocation. For a similar continuum, see Bell-Fialkoff (n. 18 above), p. 3.

${ }^{44}$ This list is not meant to be exhaustive. One might add that the targets of ethnic cleansing may be citizens or noncitizens (I excluded actions against the latter from my survey). Ethnic cleansing may be carried out by states or by stateless armies (such as UPA). In multiethnic states, it may even be carried out by one ethnic group against another without state sanction or support.

${ }^{45}$ On ethnic consolidation and ethnic dilution, see Bookman (n. 18 above), pp. 121-29.

${ }^{46}$ For personal accounts of the deportations, see Tak eto bylo. Natsional'nye repressii v SSSR, 1919-1952 gody, 3 vols. (Moscow, 1993).

${ }^{47}$ The many internationally sanctioned "population transfers" were not accompanied by intentional murder but had almost always been preceded, during the previous war, by the terrorization and massacre of the population to be deported. 
Soviet ethnic cleansing was professionalized to an unprecedented degree. ${ }^{48}$ The deportations were carried out with extraordinary speed and efficiency by enormous cohorts of well-trained security police in close cooperation with officials in transport, housing, food supply, and other bureaucracies. ${ }^{49}$ The local civilian population was intentionally demobilized. However, as we shall see, to some extent popular sentiment was reflected in the choice of targeted ethnic groups. Soviet ethnic cleansing began in the mid-1930s with the partial removal of stigmatized ethnic groups from the western border regions (combined with ethnic dilution through their replacement with demobilized Red Army soldiers), ${ }^{50}$ but by August 1937 it had escalated into total removal, which would remain the typical pattern (with a few exceptions) until Stalin's death. Soviet ethnic cleansing was mostly domestic (involving transfers away from sensitive border regions), but after World War II the Soviet Union also took part in international population exchanges. ${ }^{51}$ Finally, almost all ethnic cleansing in our survey took place during or in the immediate aftermath of war, whereas, while Soviet ethnic cleansing intensified during World War II, it had already begun in 1935 and continued through to Stalin's death in $1953 . .^{52}$ To sum up, then, Soviet ethnic cleansing was distinctive in the degree of its professionalization (including the professionalization of mass murder), the extent of its commitment to total ethnic removal, and especially its practice of ethnic cleansing in conditions of peace.

To conclude this comparative discussion of Soviet ethnic cleansing, I will say a final word about my use of the term "ethnic cleansing," since it is a novel and controversial one..$^{53}$ I have shown that the forcible removal of an ethnically defined population from a given territory has been a widespread and crucial phenomenon of the twentieth century, and particularly so in the Eurasian bor-

${ }^{48}$ The only exception to this statement would be the Red Army's actions in eastern Europe, where mass rape and violence were used indiscriminately to punish the local German population and to intimidate them into fleeing the territory of postwar Poland and Kaliningrad oblast. See de Zayas (n. 37 above); and Norman M. Naimark, The Russians in Germany: A History of the Soviet Zone of Occupation, 1945-1949 (Cambridge, Mass., 1995), pp. 69-140.

${ }^{49}$ The organization of the deportations is documented very well in Belaia kniga o deportatsii koreiskogo naseleniia Rossii v 30-40-kh godakh. Kniga pervaia (Moscow, 1992); and Deportatsiia (n.34 above).

${ }^{50}$ As we shall see, the Soviet Union also engaged in ethnic consolidation. Forced assimilation, in contrast, was largely absent from Soviet nationalities policy.

${ }^{51}$ Given the Red Army's presence in Poland and the participation of the Communistdominated Lublin Committee, the Polish-Soviet population exchange was at least quasidomestic.

52 The connection between ethnic cleansing and war is hardly confined to the Eurasian borderlands. See Panikos Panayi, ed., Minorities in Wartime: National and Racial Groupings in Europe, North America and Australia during the Two World Wars (Oxford, 1993).

${ }^{53}$ Again, on the controversy, see Hayden (n. 16 above); and Ahmed (n. 16 above). 
derlands. Since ethnic cleansing has emerged as the most accepted term to denote this practice in both popular and scholarly usage, I have employed it. Other terms - population transfer, forced migration, mass expulsion - are not appropriate for all instances of the forcible removal of an ethnically defined population from a given territory. Moreover, "ethnic cleansing" does have the advantage of accurately representing the perspective of the perpetrator. It is the perpetrator who provides the ethnic definition of the targeted group, which may or may not coincide with the population's self-definition. ${ }^{54}$ And it is the perpetrator who views the removal of this population as "cleansing." Like the Serbs in the early 1990s, the Soviet government used the term "cleanse" (ochistit', ochistka) to describe the deportation of ethnic groups from its border regions. ${ }^{55}$ The Nazi state likewise used the term for its ethnic cleansing and genocidal actions, as did the imperial Russian government during World War I and the Czechoslovak government after World War II. ${ }^{56}$

\section{The Background to Soviet Ethnic Cleansing}

I excluded one important variable from the preceding comparative discussion of ethnic cleansing: the type of state engaging in ethnic cleansing and its goals in doing so. The states involved in ethnic cleansing in my survey were all either nation-states (the overwhelming majority, including almost all the new states of eastern Europe), movements aspiring to form nation-states (UPA), or empires attempting to transform themselves into nation-states (the late Ottoman

\footnotetext{
${ }^{54}$ Although a distinctive modern practice, ethnic cleansing would appear to be particularly common in transitional states (the late Ottoman and Russian Empires, the early Soviet Union, the newly formed states of eastern Europe) and often targets groups in transition from ambiguous ethno-estate identities (such as the ethno-religious millets in the Ottoman Empire or ethno-soslovie categories such as the German colonists in the Russian Empire and Soviet Union) to modern ethnic identities.

${ }^{55}$ Tsentral'nyi derzhavnyi arkhiv hromads'kykh ob'ednan' Ukrainy (hereafter TsDAHOU) fond 1, opis' 6, delo 396 (19.06.35), p. 166 (hereafter fond/opis'/delo [date]: page), $1 / 16 / 12$ (29.09.35): 229, and 1/16/12 (04.11.35): 343 . For the same usage in later Soviet deportations, see Bugai, L. Beriia (n. 9 above), pp. 149, 164, 189, 190. Cleansing (chistka, ochistka) was a common term in the Bolshevik vocabulary, used in particular to refer to the routine expulsion of members of the Communist Party deemed unworthy, as well as to the arrest or deportation of members of various stigmatized population categories.

${ }^{56}$ On Imperial Russian usage, see Lohr (n. 22 above), chaps. 2-3; Nazi German usage in the form of the term "judenrein" is well known; on Czechoslovak usage of the term "cleansing" (ocista) for the general process of cleansing the state, which included the removal of all Germans, see Benjamin Frommer, "Unmixing Marriage in Postwar Czechoslovakia" (paper presented at the Harvard Ukrainian Research Institute, April 1998). Cited with author's permission. Presumably many other perpetrators use the term "cleansing."
} 
and Russian empires).$^{57}$ In each case, their goal in carrying out ethnic cleansing was to further their ethnic homogeneity (and, in some cases, to establish demographic claims for territorial expansion). The Soviet Union had no ambition to transform itself into an ethnically homogeneous nation-state, but it still engaged in large-scale ethnic cleansing over an extended period of time. Why? Although Soviet ethnic cleansing was a phenomenon of the 1930s, the era of the Great Terror, its origins lay in the 1920s. Accordingly, I will begin by analyzing an important set of Bolshevik conceptual categories and practices from that time period, which served as preconditions for the emergence of Soviet ethnic cleansing.

The first of these was ethnically based agricultural resettlement. In the 1920s, Soviet policy was marked by a commitment to ethnic proliferation. All Soviet nations, no matter how small, were guaranteed their own national territories. This policy led to the formation of a byzantine network of national territories, servicing around one hundred different nationalities and including several dozen large national republics and oblasts, several hundred national regions (population 10,000-50,000) and several thousand national townships (population 500-5,000). ${ }^{58}$ Not all nations, however, were conveniently territorially concentrated. In some cases, it was necessary to resettle members of ethnic groups in compact agricultural settlements so that they could form their own national territories - in other words, to engage in a policy of ethnic consolidation.

The largest such program led to the creation of a Jewish autonomous oblast in the far eastern region of Birobidzhan, as well as four Jewish national regions and seventeen Jewish townships in Crimea and south Ukraine. ${ }^{59}$ Gypsies and Assyrians were likewise resettled in compact groups to form national territories. ${ }^{60}$ Nomadic Kalmyks on the North Caucasus steppe were concentrated in a single national region. ${ }^{61}$ Karelians were resettled from central Russia to bolster the population of the Karelian Autonomous Soviet Socialist Republic (ASSR).

${ }^{57}$ The Nazi German state is something of an exception here, since its goal was to form a territorially expanded German nation-state as the dominant core of a multiethnic empire. The Tsarist Russian Empire's deportation of Germans and Jews represented a radical intensification of its previously sporadic efforts to russify the western borderlands, but it should be pointed out that it was not accompanied by similarly aggressive russification measures elsewhere in the Russian Empire.

${ }^{58}$ Martin, "An Affirmative Action Empire" (n. 13 above), p. 605.

${ }^{59}$ Ia. Kantor, Natsional'noe stroitel'stvo sredi evreev v SSSR (Moscow, 1934); Allan Laine Kagedan, "The Formation of Soviet Jewish Territorial Units, 1924-1937” (Ph.D. diss., Columbia University, 1985), pp. 23-28; N. F. Bugai, "20-e-50-e gody: Pereseleniia i deportatsii evreiskogo naseleniia v SSSR," Otechestvennaia istoriia, no. 4 (1993), pp. $175-85$.

${ }^{60}$ GARF 1235/128/2 (1933): 110, 166.

${ }^{61}$ GARF 1235/141/1531 (1933): 103. 
When this failed, around 25,000 Finnish immigrants were recruited from Canada and the United States. ${ }^{62}$ The Soviet Union's central agency for agricultural resettlement even established a principle that, in the process of agricultural resettlement, national groups should as a rule be settled compactly ${ }^{63}$ Likewise, within each national district, free land was often reserved for migrants who belonged to the national majority ${ }^{64}$ These population transfers, it should be emphasized, were largely voluntary. Nevertheless, they established, already in the 1920s, the principle of resettlement of populations along ethnic lines.

The formation of several thousand national territories naturally had an immense impact on ethnic relations. The Bolshevik leadership hoped that their policy would reduce ethnic conflict by satisfying national desires and thereby enabling class-based international solidarity. In fact, the opposite occurred. Popular opinion adopted an exclusive attitude toward national territories, insisting on the majority's right to dominate their own (nash) national region. This led to an intolerance toward national outsiders, who were frequently told to return to "their" (svoi) national territory: "Get out of Uzbekistan, go to your own (svoi) Turkmenistan"; or "The Kirgiz have their own republic, where they should go to get land." ${ }^{65}$ The fact that the Soviet state itself sanctioned the movement of ethnic populations in order to form national territories naturally enhanced and legitimized this attitude.

However, only under certain conditions did this feeling of national exclusivity go beyond rhetoric and lead to actual attempts at violent popular ethnic cleansing. In general, four conditions combined to create such a heated atmosphere: conflicts over land and national territory between groups that were divided along status and ethnic lines. By status, I mean the prerevolutionary categories that gave different privileges to different status groups (sosloviia) ${ }^{66}$ For example, Cossacks and foreign colonists were given legal rights denied to ordinary Slavic peasants, while nomadic Asians (inorodtsy) and immigrant Koreans had a lower-status ranking. In rural regions, higher-status groups invariably possessed more land. As a result, when status and ethnic categories overlapped, conflicts between different status groups over land possession became inter-

${ }^{62}$ Michael Gelb, “'Karelian Fever': The Finnish Immigrant Community during Stalin's Purges," Europe-Asia Studies 45 (1993): 1091-1116.

${ }^{63}$ "V sovete natsional'nostei SSSR," Revoliutsiia i natsional'nosti, no. 1 (1930), p. 111.

${ }^{64}$ TsDAHOU 1/20/2019(1925), p. 171; “VUTsIK USSR," Sovetskoe stroitel'stvo, nos. 5-6 (1928), pp. 218-19.

${ }^{65}$ These are two of hundreds of similar quotations from OGPU informational reports. Rossiiskii Tsentr Khraneniia i Izucheniia Dokumentov Noveishei Istorii (RTsKhIDNI) 62/2/882 (1927): 274, and 62/2/1808 (1929): 134; Martin, "An Affirmative Action Empire," pp. 521-58.

${ }^{66}$ Gregory L. Freeze, "The Soslovie (Estate) Paradigm and Russian Social History," American Historical Review 91 (1986): 11-36. 
twined with conflicts over the formation of national territories. When the national majority of a new national territory came from a formerly low-status group, they often attempted to use their new political power to seize the formerly dominant-status group's land and drive it out of the new national territory. I will refer to this as popular ethnic cleansing.

The most striking example of popular ethnic cleansing took place in Kazakhstan. In the last two decades of Tsarist rule, a large number of Slavic peasants had been settled on land traditionally utilized by Kazakh nomads. ${ }^{67}$ The resulting ethnic and status tension exploded in the bloody 1916 Kazakh uprising and the postrevolutionary civil war, both of which pitted Russian Cossacks and Slavic settlers against the local Kazakh and Kirgiz population. ${ }^{68}$ During these conflicts, the Kazakh population suffered severe repressions and Russian settlers seized still more land. In September 1920, the Soviet government decreed a set of reparations aimed at reconciling the local population, including the removal of illegal Russian settlers, the equalization of native and European landholdings, and the prohibition of future settlement. ${ }^{69}$ These reforms, carried out in 1921-22, resulted in a mass expulsion of Slavic settlers and Cossacks. ${ }^{70}$ Kazakhstan's Russian population declined by 19.5 percent and its sewn area of crops by 50.6 percent. $^{71}$ The center quickly lost control of the land reform. Unauthorized "special punitive expeditionary missions" attacked settler villages. ${ }^{72}$ Entire Russian villages were "in twenty-four hours . . driven out into the frost." 73 The process, a central investigation later concluded, "took place with excessive cruelty and took on the character of revenge." ${ }^{74}$ At the end of 1922 the land reform was officially halted, but, despite stringent central efforts, Russian settlers continued to be driven off their land in both Kazakhstan and Kirgizia as late as $1927 . .^{75}$

A similar situation prevailed in the North Caucasus. During Tsarist rule, the indigenous mountain peoples (gortsy) had been progressively driven out of the more fertile Caucasian foothills deeper into the mountains. Their land was

${ }^{67}$ George J.Demko, The Russian Colonization of Kazakhstan, 1896-1916 (Bloomington, Ind., 1969).

${ }^{68}$ Edward Dennis Sokol, The Revolt of 1916 in Russian Central Asia (Baltimore, 1953).

${ }^{69}$ S'ezdy sovetov RSFSR $i$ avtonomnykh respublik RSFSR, vol. 1 (Moscow, 1959), pp. 434-36; V. L. Genis, "Deportatsiia russkikh iz Turkestana v 1921 godu ('Delo Safarova')," Voprosy istorii, no. 1 (1998), pp.44-58.

${ }^{70}$ GARF 3316/64/220 (1926): 11-14ob.

${ }^{71}$ GARF 3316/16a/177 (1924): 28-31. These statistics refer to the population within the post-1924 Kazakh ASSR borders.

${ }^{72}$ Ibid.

${ }^{73}$ GARF 1235/140/127 (1926-28): 39.

${ }^{74}$ GARF 3316/64/220 (1926): 13. See also Genis, pp. 46-54.

${ }^{75}$ Martin, "An Affirmative Action Empire” (n. 13 above), pp. 532-48. 
granted first to Cossacks and then to Slavic settlers. As in Kazakhstan, the resulting ethnic tension led to brutal national conflict during the civil war. The first act of the newly formed Mountaineer ASSR in 1921 was to redress this historic grievance: "For the satisfaction of the desperate needs of landless Mountaineers, immediately begin the planned expulsion of Cossack settlements beyond the borders of the Mountaineer ASSR." ${ }^{76}$ In fact, on central orders, the liquidation of numerous Terek Cossack settlements had already begun. ${ }^{77}$ Their land was given to landless gortsy. These deportations punished the Cossacks for their role in the anti-Bolshevik White movement. ${ }^{78}$ However, they were also a form of anticolonial reparation directly linked to the formation of a new mountaineer national territory. Again, this action naturally reinforced the mountaineers' feeling that all the land belonged to them. Therefore, as in Kazakhstan, although state-sanctioned deportations ceased in 1922, it took years for the state to control popular gortsy efforts to expel Russian settlers and Cossacks. ${ }^{79}$

Other regions witnessed similar hostility. In the Far East, popular hostility between Russian settlers and Korean immigrants led to insistent demands by the former that the latter be physically removed from the region..$^{80}$ In this case, it was the higher-status Russians who were attempting to expel the lower-status Korean immigrants. In the Soviet Union's western border regions, conflict arose between the prosperous western national minorities (in particular Germans, Poles, and Finns, many of whom belonged to the prerevolutionary colonist or landowner sosloviia) and the local Slavic peasantry. ${ }^{81}$ This popular animosity resulted in violence during the civil war, simmering tensions during the mid-1920s and, as we shall see, open conflict again during the anarchic period of collectivization. Western national minorities and Koreans would be the first targets of Soviet ethnic cleansing.

In the 1920s, then, the Soviet state was already willing to sanction two forms of ethnic resettlement. First, it quite unambiguously supported the voluntary resettlement of dispersed ethnic groups in order to facilitate the formation of national territories. Second, in two isolated cases, central authorities sponsored

${ }^{76}$ S'ezdy sovetov RSFSR i avtonomnykh respublik RSFSR, p. 718.

${ }^{77}$ N. F. Bugai, “20-40-e gody: Deportatsiia naseleniia s territorii evropeiskoi Rossii," Otechestvennaia istoriia, no. 4 (1992), pp. 37-40. For documents, see N. F. Bugai, "Kazaki," Shpion, no. 1 (1993), pp. 40-55.

${ }^{78}$ For an excellent study of anti-Cossack actions on the Don, see Peter Holquist, “'Conduct Merciless Mass Terror': Decossackization on the Don, 1919," Cahiers du monde russe 38 (January-July 1997): 127-62.

${ }^{79}$ Bugai, "Kazaki," pp. 52-55.

${ }^{80}$ RTsKhIDNI 17/87/199 (1925): 96.

${ }^{81}$ This was most dramatically evident in the treatment of Germans by the Makhno movement. See Dietrich Neufeld, A Russian Dance of Death: Revolution and Civil War in the Ukraine (Winnipeg, 1977). 
a limited removal of settler populations from newly formed national territories as a form of postcolonial reparation. In neither case did the Soviet state itself conceive of these deportations as ethnic. In Kazakhstan, only recently arrived illegal settlers were to be removed. In the North Caucasus, collective punishment was meted out against a hostile soslovie group. Nevertheless, the local national population most certainly did conceive of these deportations as national in nature and supported them overwhelmingly for exactly that reason. Moreover, the regime understood these popular sentiments and was temporarily willing to indulge them.

\section{The Piedmont Principle and the Soviet Border Regions}

It was the Soviet leadership's strong commitment to forming a multinational state, rather than any hostility to ethnic identities, that politicized ethnicity by linking it to the formation of administrative territories, land possession, and resettlement. This domestic nationalities policy was then further linked to Soviet foreign policy goals. In order to explore this linkage, I will introduce two further Bolshevik concepts - Soviet xenophobia and the Piedmont Principle and show how they led to the formation of a novel Soviet administrative territory: the border regions. By Soviet xenophobia, I mean simply the exaggerated Soviet fear of foreign influence and foreign contamination. I absolutely do not mean traditional Russian xenophobia. Soviet xenophobia was ideological, not ethnic. It was spurred by an ideological hatred and suspicion of foreign capitalist governments, not the national hatred of non-Russians. Foreign intervention during the civil war did not create Soviet xenophobia. It merely confirmed a preexisting ideological inclination.

Soviet xenophobia was, however, given a national focus by ongoing lowintensity guerrilla warfare and sporadic partisan uprisings along the entire Soviet frontier. Whereas foreign military intervention had been brief and discrete, guerrilla warfare involved ongoing secretive border crossings and relied on an ambiguous combination of foreign and domestic support. Most famously, the Basmachi rebellion in central Asia, which continued into the mid-1930s, relied heavily on clan and ethnic alliances linking northern Afghanistan and Soviet Central Asia. ${ }^{82}$ Major uprisings also flared up in other Soviet border regions: in Chechnia and Dagestan from 1920 to 1922, in Karelia in 1921-22, Georgia in 1924, Yakutia in 1924-25 and 1927-28, and Adzharistan in 1927 and 1929. Throughout the early 1920s, the Soviet secret police reported ongoing "political banditry" across the Polish-Ukrainian frontier. ${ }^{83}$ This deepened Soviet fears

\footnotetext{
${ }^{82}$ Baymirza Hayit, “Basmatschi”: Nationaler Kampf Turkestans in den Jahren 1917 bis 1934 (Koln, 1992).

${ }^{83}$ For example, see RTsKhIDNI 17/87/177 (1924), and 17/87/178 (1923-24).
} 
of surreptitious foreign penetration and focused Soviet xenophobia on the largely non-Russian border regions.

In July 1923, Soviet xenophobia was given an institutional embodiment by a government decree that delineated a special continuous administrative territory called "the border regions" ( pogranichnye raiony) ${ }^{84}$ All modern nations have clearly marked borders, and some have had the concept of a border region, but no nation went as far as the Soviet Union in the ideological and administrative definition of distinct border regions..$^{85}$ The 1923 decree, which was drafted by the Soviet secret police, established a series of increasingly high-security border strips running along the entire land and sea border of the Soviet Union at the depth of 4 meters, 500 meters, 7.5 kilometers, 16 kilometers, and 22 kilometers ${ }^{86}$ The entire 22-kilometer-wide border strip was placed under the special supervision of the secret police border guard, which was given an unlimited right of search and seizure. ${ }^{87}$

The 1923 decree focused exclusively on defensive security measures and so exemplified the Soviet fear of foreign influence. However, by 1925 the Soviet Union felt it had achieved an adequate degree of frontier security and now hoped to use its border regions to project Soviet influence outward, particularly along the Soviet Union's western border. To that end, in July 1925, the Soviet Politburo passed a sweeping resolution establishing a variety of privileges for the western border regions: higher salaries, more economic investment, a better supply of goods, permission to run budget deficits, and more cultural investment. ${ }^{88}$ This decree was explicitly based on the idea that "our border regions are that part of our territory by which the workers of neighboring nations concretely judge the Soviet Union." ${ }^{89}$

Nationalities policy was a crucial component of the Soviet border regime. The Soviet government was particularly concerned about the loyalty of the border regions' Finnish, Polish, and German populations. A 1925 investigation reported that the Leningrad Finnish population was exposed to a strong "Finnish influence, due to both historic and cultural ties, and the efforts of Finland herself, who tries in all ways to widen her sphere of influence on the Finnish population of our border regions." ${ }^{90}$ Similar concerns were registered about

${ }^{84}$ GARF 3316/16a/22 (1923): 3-12; RTsKhIDNI 17/3/339 (08.03.23): protokol 53/ punkt 6 .

${ }^{85}$ On the Imperial German borderlands, see Hagen (n. 24 above). On Imperial Russia, see Terry Martin, “The Empire's New Frontiers: New Russia's Path from Frontier to Okraina, 1774-1920," Russian History 19 (1992): 181-201.

${ }^{86}$ GARF 3316/16a/22 (1923): 4.

${ }^{87}$ Ibid., pp. 3-7; also GARF 3316/64/218 (1925): 51.

${ }^{88}$ RTsKhIDNI 17/3/511 (16.07.25): 71/34.

${ }^{89}$ GARF 1235/120/11 (1925): 4.

${ }^{90}$ GARF 374/27/594 (1925): 4. 
the Soviet Union's Polish and German populations. ${ }^{91}$ Given these security concerns, one might have expected the Soviet government to restrict national selfexpression in the border regions. In fact, the exact opposite was the case. The 1925 Politburo decree specifically stipulated that national minorities in the border regions should be given more national rights than those in the central regions of the Soviet Union. There should be more national schools, more national territories, an expanded native-language press, aggressive recruitment and promotion of national cadres, and strict punishment of all Russian chauvinism. ${ }^{92}$ Far from attempting to further ethnic homogeneity, the Soviet government consciously aimed to emphasize and promote the ethnic diversity of their border regions.

This somewhat surprising policy was aimed at promoting Soviet foreign policy goals. The Soviet Union's western border, along its entire length, cut through the ethnographic territory of Finns, Belorussians, Ukrainians, and Romanians. Soviet policy aimed to exploit this situation: the leadership hoped that a generous policy toward these nationalities within the Soviet Union would attract their ethnic brethren in Poland, Finland, and Romania. As one official put it: "The Soviet Polish population lives largely in our border regions with Poland and so the execution of our nationalities policy with regard to the Polish population will help revolutionize the foreign Polish population."93 The Moldavian ASSR was formed in 1924 as part of an effort to provoke an uprising in Romanian Bessarabia. ${ }^{94}$ The Karelian ASSR was formed and staffed by emigre Finnish Communists to provide an exemplary model of Finnish Communism situated directly on Finland's eastern border. ${ }^{95}$

Ukrainian Communists were particularly avid supporters of this strategy. They hoped to expand Soviet Ukraine to include majority Ukrainian territory in Poland, Romania, and Czechoslovakia. Their favorite metaphor for this process was "Ukraine as Piedmont": "There was a time when Galicia served as the "Piedmont" for Ukrainian culture. Now, when Ukrainian culture is suffocating in "cultured," "european" Poland, its center has naturally shifted to the Ukrainian SSR.” 96 In this metaphor, Soviet Ukraine would serve as the center for the political and cultural unification of the divided Ukrainian population, the role Piedmont had played for Italy in the nineteenth century. Therefore, a prominent Ukrainian Communist, Mykola Skrypnyk, titled an article "The

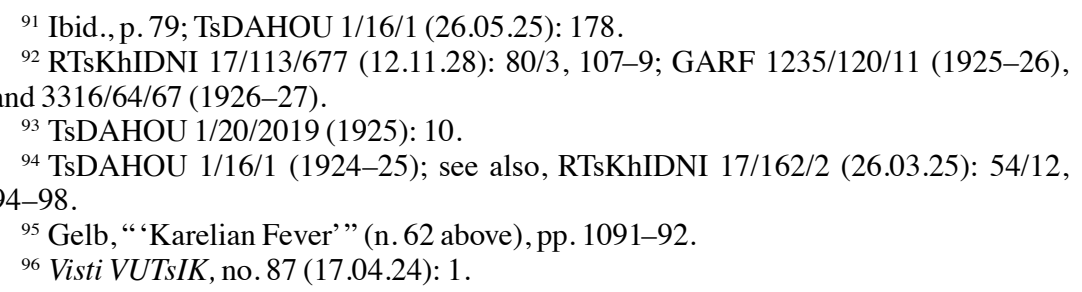


Ukrainian SSR - Piedmont of the Ukrainian Laboring Masses,"97 while another Ukrainian Communist, Volodymyr Zatonskyi, called the Moldavian ASSR our "Moldavian Piedmont" and the Karelian ASSR a "Karelian Piedmont." ${ }^{98}$ Borrowing this favorite Ukrainian metaphor, I will refer to the Soviet attempt to exploit cross-border ethnic ties to project Soviet influence abroad as the Piedmont Principle.

A fundamental tension, then, lay at the heart of the Soviet nationalities policy in the border regions. Soviet xenophobia encouraged ethnic suspicions and a restriction on national self-expression, while the Piedmont Principle dictated an ostentatious promotion of national institutions. Throughout the 1920s, the latter tendency prevailed. It would take a series of domestic- and foreignpolicy shocks to eventually provoke an abandonment of the ethnophilia of the 1920 s and a turn toward the ethnic cleansing of the 1930s. In both the 1920s and 1930s, however, the adopted policy was based on the exact same premise: the Bolsheviks' strong belief in the political salience of cross-border ethnic ties.

\section{The Politics of ImMigRation}

This tension between Soviet xenophobia and the Piedmont Principle was perhaps most dramatically exemplified in the Soviet attitude toward immigration. On the one hand, immigration was a victory for the Piedmont Principle, demonstrative evidence that the Soviet Union was attractive to cross-border populations. On the other hand, immigration was feared as an easy cover for foreign espionage. Still, despite this latter concern, illegal immigrants were usually not deported. In fact, they were granted the same national rights as indigenous Soviet nationalities. For instance, Afghan immigrants (Beluchi, Dzhemshid, Khazara) were given land in the border regions, their own national territories, and other national rights: "A positive Soviet mood among them will evoke sympathy and attract to us class-friendly elements from the foreign [Afghan] border regions." 99

If the Soviet government nervously accepted new, immigrants, it actively solicited the return of most non-Russian, Soviet emigres. Treaties with Finland and Poland both stipulated the right of emigres to return to the Soviet Union. About 12,000 Finns and many more Poles took up this offer of amnesty. ${ }^{100}$

\footnotetext{
${ }^{97}$ Mykola Skrypnyk, Statti i promovy. Natsional'ne pytannia.Tom II. Chastyna Druha (Kharkov, 1931), pp. 153-59.

${ }^{98}$ GARF 3316/64/933 (1931): 28.

${ }^{99}$ RTsKhIDNI 62/2/2205 (1930): 6, 33-34; RTsKhIDNI 62/1/829 (18.03.31), 62/1/ 467 (30.04.28), 62/1/882 (27.06.31), 62/3/465 (15.01.29): 18-23.

${ }^{100}$ Matley (n. 9 above), p. 5; Iwanov (n. 9 above), p. 72.
} 
Efforts were likewise made to entice Volga German emigres to return. ${ }^{101}$ In central Asia, where the civil war and Basmachi uprising led to massive emigration, the government undertook aggressive measures to improve the economic conditions, of its, border regions and thereby to prevent further emigration and lure back emigres: "It is politically extremely negative, that every year in the Afghan border regions, more and more forces openly hostile to us are gathering which, if political conditions worsen, will be used against us." ${ }^{102}$

In Ukraine and Belorussia, the return of immigrants was directly linked to the Piedmont Principle. In both republics, leaders of civil war-era antiBolshevik nationalist governments and movements were encouraged to return and take part in the new Soviet project of building Ukrainian and Belorussian culture. Even Mykhailo Hrushevskyi, the famous Ukrainian historian and president of the Central Rada during its conflict with the Bolsheviks in 1917-18, was given permission to return in 1924 and was appointed head of the Historical Section of the Ukrainian Academy of Sciences, allowed to edit a popular historical journal, and almost elected president of the entire academy. ${ }^{103}$ This policy, which aimed at popularizing and legitimizing the Soviet nationalities policy among cross-border national populations, was one of the most striking instances of the Piedmont Principle in action.

However, the recruitment of immigrants also provoked considerable anxiety. On his return, Hrushevskyi was immediately placed under comprehensive secret police surveillance. ${ }^{104}$ Illegal immigrants were frequently moved away from the border regions to thwart potential espionage. ${ }^{105}$ This concern about immigrants was most evident in the Soviet Far East, where a massive influx of Koreans had created extremely tense ethnic relations. From 1917 to 1926, the Soviet Korean population tripled from 53,600 to $168,009 .{ }^{106}$ By 1926 , Koreans represented over a quarter of the rural population of the Vladivostok region $(145,511$ of 572,031$) .{ }^{107}$ There was an enormous class and status difference between Koreans and Russians. In 1922, 84.3 percent of Korean households

${ }^{101}$ RTsKhIDNI 17/3/517 (27.08.25): 77/12.

${ }^{102}$ RTsKhIDNI 62/2/1261 (1928): 1. On measures taken, see RTsKhIDNI 62/1/1106 (27.02.33): 92-102,62/1/467 (30.04.28): 240-49, 62/1/829 (18.03.31): 49-61.

${ }^{103}$ On Hrushevskyi's return and last years in Ukraine, see Ruslan Pyrih, Zhyttia Mykhaila Hrushevskoho: ostannie desiatylittia, 1924-1934 (Kiev, 1993); Iurii Shapoval and Volodymyr Prystaiko, Mykhailo Hrushevskyi i HPU-NKVD. Trahichne desiatylittia: 1924-1934 (Kiev, 1996).

${ }^{104}$ Shapoval and Prystaiko, pp. 130-32.

${ }^{105}$ RTsKhIDNI 62/1/467 (30.04.28): 248-49, 62/1829 (18.03.31): 51.

${ }^{106}$ GARF 1235/140/141 (1925): 4; S. D. Anosov, Koreitsy v ussuriiskom krae (Khabarovsk-Vladivostok, 1928), pp. 7-8; Vsesoiuznaia perepis' naseleniia 1926 goda. Tom VII (Moscow, 1928), p. 8.

${ }^{107}$ Vsesoiuznaia perepis'. Tom VII, pp. 126-27. When one includes the city of Vladivostok, Koreans represented 22.4 percent of the population. 
were landless and only 32.4 percent even possessed Soviet citizenship. ${ }^{108}$ In 1925, 68.8 percent of Koreans still cultivated exclusively rented land (vs. 7.8 percent of Russians). The average Korean household possessed less than onethird the land of local Russians (15.9 vs. 4.6 acres). ${ }^{109}$ Conflict centered on land possession, since Soviet policy called for transferring land to those who cultivated it. This meant giving Russian land to immigrant Korean tenants. Russians responded by refusing to rent land and, according to the OGPU, by "demanding the resettlement of Koreans into a different region." ${ }^{110}$

However, Soviet policy, as dictated by the Piedmont Principle, demanded the exact opposite: the formation of an autonomous Korean national territory. Mass Korean immigration had eloquently demonstrated the attractiveness of the Soviet Union for the Koreans of Japanese-occupied Korea. The formation of an autonomous Korean territory would further attract Koreans and put pressure on the Japanese colonial regime. Such was the argument of the Comintern's Eastern Department when, in May 1924, it petitioned the Soviet government to form a Korean autonomous oblast. ${ }^{11}$ This petition coincided exactly with the formation in the Soviet west of the "Moldavian Piedmont," whose goal was to put political pressure on Romania. A Korean ASSR of almost the exact same size and ethnic preponderance could have been formed. ${ }^{112}$ The proposal was seriously debated, but by 1925 it had been rejected. ${ }^{113}$

Two factors appear to explain the rejection of a Korean ASSR. Most importantly, the Soviet leadership felt politically and militarily weak in the Far East. They were, therefore, more concerned over potential Japanese influence on the Soviet Korean population than over projecting Soviet influence into Japaneseruled Korea. A 1929 government report bluntly stated that Japan viewed Korean immigration to the Soviet Union "as the natural expansion of the boundaries of Korea, which at the proper moment could be claimed formally." ${ }^{114}$ This fear led the Foreign Ministry in January 1926 to demand emergency measures to stop Korean immigration. ${ }^{115}$ In addition, the Far Eastern Communist leadership gave expression to popular ethnic hostility. They supported the local

${ }^{108}$ GARF 1235/140/141 (1925): 6; Anosov, p. 29.

${ }^{109}$ GARF 1235/140/141 (1925): 4.

${ }^{110}$ RTsKhIDNI 17/87/199 (1925): 96.

${ }^{111}$ GARF 1235/140/141 (1924): 20-34; for earlier efforts, see Belaia kniga (n. 49 above), pp. 40,46-47.

112 The Moldavian ASSR had a Moldavian population of 170,263 out of a total population of 572,339 (29.7 percent Moldavian). A Korean ASSR with 152,424 Koreans out of 680,011 (22.4 percent) could have been formed, or a smaller territory with a Korean majority $(85,299 / 157,438=52.4$ percent $)$ could have been established. Martin, "An Affirmative Action Empire" (n. 13 above), p. 714.

${ }^{113}$ GARF 1235/140/141 (1924-25): 42-47.

${ }^{114}$ GARF 374/27s/1706 (1929): 3.

${ }^{115}$ GARF 1235/140/141 (1926): 141ob. 
Russian view of Koreans as potentially disloyal and economically detrimental illegal aliens who should be resettled away from the sensitive border regions. ${ }^{116}$

As a result, a contradictory policy emerged. On the one hand, smaller Korean national territories were authorized: one Korean national region and 171 Korean townships. ${ }^{117}$ Korean-language schools and newspapers were established. ${ }^{118}$ A Far Eastern national minorities bureaucracy was formed with a plenipotentiary on Korean affairs. Koreans were systematically promoted into the Far Eastern bureaucracy. ${ }^{119}$ This policy line presented Koreans as a model Soviet national minority to be poignantly and publicly contrasted with the wretched Koreans living under Japanese colonial occupation.

On the other hand, at the exact same time this policy line was being implemented, the central government issued a secret decree (December 6, 1926) confirming a plan to resettle most Koreans north of the 48.5th parallel (north of Khabarovsk). According to this decree, all Koreans who had not yet received land - slightly over half the population - would be resettled to the north. ${ }^{120}$ Two large land funds were reserved for the Koreans. When this policy was justified publicly (which was rare), it was portrayed as analogous to Jewish resettlement. Landless nationals were to be resettled compactly onto free government land, to provide them with land and to allow them a better opportunity to develop their national culture. ${ }^{121}$ The comparison, however, was specious. Dispersed Jews were being concentrated voluntarily on excellent agricultural land. Koreans were already territorially concentrated on good agricultural land and were to be involuntarily dispersed and then immediately replaced with Slavic peasants from central regions. ${ }^{122}$ It was this last measure that most infuriated Korean Communists, since it clearly implied that the Soviet Koreans were disloyal. ${ }^{123}$

The Korean resettlement program would have been the first instance of Soviet ethnic cleansing, had it in fact been implemented. However, through the end of 1928, virtually nothing had been done. ${ }^{124}$ The opposition of Korean

${ }^{116}$ GARF 1235/140/141 (1925): 54-75; Belaia kniga, 46-49. Gelb, "An Early Soviet" (n. 9 above), pp. 394-95.

${ }^{117}$ GARF 374/27s/1706 (1929): 25; S. G. Nam, Koreiskii natsional'nyi raion: Puti poiska issledovatelia (Moscow, 1991).

${ }^{118}$ Anosov (n. 106 above), pp. 80-84.

${ }^{119}$ GARF 1235/120/60 (1927): 71-78; Belaia kniga, 37-39; GARF 374/27s/1706 (1929): 28.

${ }^{120}$ GARF 1235/140/141 (1926): 144.

${ }^{121}$ See the propaganda instructions in GARF 1235/120/60 (1928): 17-20. Anosov obliquely mentions resettlement. Anosov, p. 64.

${ }^{122}$ GARF 1235/140/141 (1926): 144.

${ }^{123}$ GARF 1235/140/141 (1928): 146-52.

${ }^{124}$ GARF 1235/141/1356 (1931): 3, 3316/64a/1078 (1931): 5, 374/27s/1706 (1929): 7-9. 
communists, passive resistance of Korean peasants, absence of central funding, lack of Russian settlers, and a deeply contradictory state policy caused the resettlement plan to go unfulfilled. Nevertheless, the law remained formally in effect and served to stigmatize the Soviet Koreans. In the Far East, then, a rough kind of balance between Soviet xenophobia and the Piedmont Principle prevailed. Before full-scale ethnic cleansing could emerge in either the Far East or the western border regions, two further policy shocks would have to occur.

\section{Collectivization ANd EMigration}

The first shock came in the form of collectivization and the emigration movement it triggered. The reintroduction of coercive grain requisitions in the winter of 1927-28 immediately reversed the existing immigration flow. Central Asia and the Transcaucasus reported a sudden growth in emigration and plans to emigrate. ${ }^{125}$ The most dramatic and politically consequential emigration movement, however, took place in the fall of 1929. In September 1929, Soviet citizens of ethnic German descent began to converge on Moscow to demand exit visas to leave the Soviet Union permanently. Word of this development soon reached the German embassy, who sent out a representative to investigate. He was accompanied by two German and three American correspondents. They found that about 4,500 Germans, mostly Mennonites, had congregated in the Moscow suburbs. The Germans told of horrible repression and reported they had sold or abandoned all their possessions and were resolved to emigrate to Canada. ${ }^{126}$

The foreign correspondents immediately published sensational accounts of the repression these German peasants had suffered, which in turn triggered a storm of media coverage and provoked a significant political scandal in Germany. ${ }^{127}$ An organization, "Brothers in Need," was formed to raise money for the Soviet Germans, and President Hindenberg himself donated 200,000 Marks of his own money. ${ }^{128}$ The German embassy, which previously had refused to intervene on behalf of ethnic German Soviet citizens, so as not to offend their Soviet hosts, now interceded aggressively on their behalf. ${ }^{129}$ Sur-

${ }^{125}$ RTsKhIDNI 62/2/1261 (1928): 1-17, 42-43, 75-76, and 157/5/83 (1927): 229-30.

${ }^{126}$ From 1923 to 1926, around 20,000 Mennonites had been permitted to emigrate to Canada. They now sought to resume this movement. Captured German Materials (hereafter CGM), microfilm reel 4763 (11.10.29): L192465-75; Harvey Dyck, Weimar Germany and Soviet Russia, 1926-1933 (New York, 1966), pp. 162-74; Meir Buchsweiler, Volksdeutsche in der Ukraine am Vorabend und Beginn des Zweiten Weltkriegsein Fall doppelter Loyalitaet? (Gerlingen, 1984), pp. 58-64.

${ }^{127}$ Dyck, p. 163.

${ }^{128}$ Ibid., p. 171.

${ }^{129}$ CGM reel 5213 (01 .08.29): K480944-49, reel 4763, L192270-475. 
prised by this unexpected development, the Soviet government behaved erratically, first allowing 5,461 Germans to emigrate and then deporting the remaining 9,730 to their original places of residence. ${ }^{130}$ The episode ended up embarrassing the Soviet government at the height of the collectivization drive and significantly souring Soviet-German relations.

In theory, collectivization was not supposed to have an ethnic dimension, but in practice it quickly developed one. The anarchy and violence of collectivization, with its sudden reversal of the NEP order, enabled the expression of ethnic hostility. Where sentiments of popular ethnic cleansing existed, NEP "losers" took revenge. In Kazakhstan, Russians revenged themselves on the suddenly vulnerable Kazakh nomads. ${ }^{131}$ Likewise, in Ukraine, popular opinion viewed all Germans as kulaks. A Central Committee report noted that "certain high officials have the incorrect opinion that all German villages are exclusively kulak." ${ }^{132}$ Another Communist put it more colorfully: all Germans were "kulak colonizers to the marrow of their bones." 133 The numerous internal reports attempting to explain the emigration movement unanimously agreed that these sentiments had led to an exceptionally harsh treatment of Germans during collectivization. ${ }^{134}$ Such popular attitudes had likewise surfaced during the civil war and were linked to the Germans' privileged prerevolutionary status.

Similar treatment helped inspire the development of smaller emigration movements in 1929-30 among almost all of the Soviet Union's "western national minorities": Poles, Finns, Latvians, Greeks, Estonians, Lithuanians, Czechs, Swedes, Bulgarians. ${ }^{135}$ These movements consisted largely of group and individual petitions to Soviet authorities and foreign consuls. There were also demonstrations and, most disturbing for the Soviets, illegal flight across the western border. ${ }^{136}$ The most active were the Poles, who were also subjected to the greatest degree of popular and local Communist hostility during collectivization. ${ }^{137}$ The popular identification of Pole and kulak was summed up in the rhyme: "raz Poliak-znachit kulak." ${ }^{138}$ Poles were bluntly told, "You are

${ }^{130}$ GARF 3316/64/759 (1929-30).

${ }^{131}$ RTsKhIDNI 94/1/1 (1928): 625-85; Martin, “An Affirmative Action Empire” (n. 13 above), pp. 547-48.

${ }^{132}$ RTsKhIDNI 17/113/786 (16.10.29): 126/6, 44 .

${ }^{133}$ GARF 1235/141/561 (1930): 59.

${ }^{134}$ RTsKhIDNI 17/113/786 (16.10.29): 160/6, 42-46, and 17/113/822 (06.02.30): 181/4, 1-250; GARF 1235/141/561 (1930), 3316/64/928 (1930), 3316/64/759-761 (1929-30).

${ }^{135}$ For the OGPU's evaluation, see GARF 3316/64/760 (1930): 95-98; in general, see GARF 3316/64/760 (1930), 3316/64/928 (1930), 3316/23/1356 (1930): 14-15.

${ }^{136}$ GARF 3316/23/1360 (1930): 6-6ob, 3316/64/928 (1930): 12-16.

${ }^{137}$ GARF 1235/141/561 (1930): 135-37, 3316/23/1360 (1930): 6, 3316/23/1318 (1930): 12-15.

${ }^{138}$ GARF 3316/64/760 (1930): 79; also quoted in GARF 3316/64/928 (1930): 15. 
being dekulakized not because you are a kulak, but because you are a Pole." 139 This reflected a widespread sentiment of popular ethnic cleansing, exemplified in this comment from a Russian village: "If he's a Pole, he annoys us and should be driven out of the village, as a foreign element." ${ }^{140}$ Hundreds of Poles, including many Communists, succeeded in fleeing across the well-guarded Polish-Soviet border. ${ }^{141}$ Other Poles engaged in mass demonstrative marches to the border, in crowds of up to 2,000 , to publicize their demand to be allowed to emigrate. ${ }^{142}$

These emigration movements dramatically confronted the Soviet leadership with the failure of the Piedmont Principle. The Soviet Union's western national minorities were meant to serve as attractive Communist examples for their ethnic brethren abroad. Instead, they themselves had been attracted by their respective "home" countries and had repudiated their Soviet fatherland in an exceedingly embarrassing fashion. In addition to spawning these emigration movements, the non-Russian periphery in general offered more violent resistance to collectivization than did the Russian core. ${ }^{143}$ Moreover, such resistance often focused on the border regions. The Basmachi movement received crossborder assistance from related clans in central Asia. ${ }^{144}$ The worst peasant uprising of the collectivization era broke out along the Polish-Ukrainian border in late February $1930 .{ }^{145}$ Both the emigration movements and these mass uprisings deepened Soviet concerns about the loyalty of the inhabitants of their nonRussian periphery and about the security of their border regions.

Given this outcome, one might have expected dramatic policy revisions. However, the official response, in both secret and published resolutions, called instead for an intensification of the existing nationalities policy. ${ }^{146}$ The policy had not failed, it was declared, but rather had never been properly implemented and was seriously distorted during collectivization. This was not simply verbal cover for a real change in policy. Throughout 1930, enormous effort was put into increasing the number and quality of German national institutions. ${ }^{147}$ The

${ }^{139}$ GARF 3316/64/1355 (1930): 19.

${ }^{140}$ GARF 3316/64/928 (1930): 15.

${ }^{141}$ GARF 3316/64/760 (1930): 62-63.

${ }^{142}$ GARF 3316/23/1360 (1930): 6,3316/64/928 (1930): 12.

${ }^{143}$ See the extensive statistical tables in Lynne Viola, Peasant Rebels under Stalin: Collectivization and the Culture of Peasant Resistance (Oxford, 1996), pp. 100-180.

${ }^{144}$ Hayit (n. 82 above), pp. 362-75.

${ }^{145}$ Andrea Graziosi, "Collectivisation, revoltes paysannes et politiques gouvernementales a travers les rapports du GPU d'Ukraine de fevrier-mars 1930," Cahiers du monde russe 35 (1994): 437-632; TsDAHOU 1/20/3184 (1930), 1/20/3195 (1927-30), 1/20/ $2522(1927-31), 1 / 20 / 3185$ (1930).

${ }^{146}$ RTsKhIDNI 17/113/821 (06.02.30): 181/4; GARF 1235/141/561 (1930): 10-12, 23, 201,3316/16a/443 (1930): 10-12.

${ }_{147}$ There are literally thousands of pages of documents devoted to this question. GARF 1235/141/561 (1930), 3316/64/928 (1930), 3316/64/968 (1929-30), 3316/64/759-761. 
same was true for Poles and other western national minorities. ${ }^{148}$ Of course, there was also an increase in repression against "notoriously malicious elements (zavedomo zlostnye elementy)," but the policy emphasis remained on promoting, rather than attacking, national identity.

There were, however, two important exceptions. The mass processions of Poles to the Polish border particularly alarmed Soviet authorities, since they took place in late February 1930 during the mass uprising against collectivization in the Ukrainian border regions. Although this uprising involved mostly Ukrainian peasants, Poles also participated. ${ }^{149}$ The OGPU and government reports spoke of increased Polish espionage and Polish government encouragement for the uprising. ${ }^{150}$ The Soviet nightmare scenario was a mass Polish emigration movement, akin to the German one, but directed toward the Polish border rather than toward Moscow: "Recently we have registered facts that work is being undertaken in order to prepare a mass demonstrative departure of Poles from the USSR to Poland. ... There is no doubt that this campaign has the goal of preparing popular opinion to justify an armed attack on the Soviet Union." ${ }^{151}$ It was in this environment that the Soviet leadership authorized its first explicitly ethnic deportation.

On March 5, 1930, the Politburo authorized the deportation of 3,000-3,500 additional kulak families from Belorussia and another 10,000-15,000 from Ukraine, with the added stipulation, "In the first line, those of Polish nationality." ${ }^{152}$ Six days later, this deportation was referred to as an exclusively Polish operation:

From our data there is reason to believe that in the case of serious kulak-peasant uprisings in right-bank Ukraine and Belorussia - especially in connection with the coming deportation of Polish-kulak counter-revolutionary and spying elements from the border regions - that the Polish government might decide to intervene. In order to avoid this ...

5. Prepare the operation for the arrest and deportation of kulak Polish counterrevolutionary elements with great care and carry out in a maximally short period.

6. Carry out the operation of deporting kulak-Polish elements with maximum organization and without fanfare. ${ }^{153}$

Collectivization, dekulakization, the Polish emigration movement, and intense Soviet concern over the security of their border regions, then, led to the first

${ }^{148}$ GARF 3316/16a/443 (1930): 1-2,3316/64/760 (1930): 8-10.

149 TsDAHOU 1/20/3184 (1930): 17-18.

${ }^{150}$ TsDAHOU 1/20/3184 (1930): 17; GARF 3316/23/1318 (1930): 3, 15.

${ }^{151}$ GARF 3316/64/928 (1930): 1.

${ }^{152}$ RTsKhIDNI 17/162/8 (05.03.30): 119/5.

${ }^{153}$ RTsKhIDNI 17/162/8 (11.03.30): 120/72. TsDAHOU 1/16/7 (13.03.30): 154. For evidence the deportation did take place, see GARF 3316/23/1360 (1930): 6. 
case of Soviet ethnic cleansing. ${ }^{154}$ Still, after this deportation, Soviet policy toward the Poles did not undergo a dramatic change. Remarkably, in 1932 a new Polish national district was even established along the BelorussianPolish border. ${ }^{155}$

In the Soviet Far East, collectivization also provoked increased ethnic tension and growing security concerns. Anti-Korean and anti-Chinese popular violence increased dramatically from 1928 to $1932 .{ }^{156}$ This atmosphere led to a mass outflow of Chinese migrant labor. ${ }^{157}$ Approximately 50,000 Koreans also fled back to Korea. ${ }^{158}$ The authorities did not oppose this emigration. In fact, they revived plans to resettle much of the remaining Korean population away from the Soviet-Korean border. On April 13, 1928, a decree was passed calling for "the resettlement of Koreans from Vladivostok okrug and the more strategically vulnerable points of Primor'e into Khabarovsk okrug." The land of the resettled Koreans was to be transferred immediately to "settlers from overpopulated agrarian regions of the Soviet Union." ${ }^{159}$ The plan was to settle demobilized Red Army soldiers into the Far Eastern border zones to form "Red Army collective farms." ${ }^{160}$ Disloyal Koreans were to be replaced with loyal Slavs.

An official five-year plan called for resettling 88,000 Koreans (over half the Korean population) north of Khaborovsk. ${ }^{161}$ All Koreans without Soviet citizenship were to be resettled, "except those having proved their complete loyalty and devotion to Soviet power." 162 The disloyalty of the majority of Soviet Koreans was thus assumed. Anyone refusing resettlement was not threatened with arrest. Leaders of Korean village soviets that harbored illegal aliens were

${ }^{154}$ There may have been a Finnish deportation as well. The March 5 Politburo decree called for the OGPU to study the Leningrad border regions and propose measures. Groups in Finland claimed there was an ethnically targeted deportation. See The Ingrian Committee, The Ingrian Finns (Helsinki, 1935), p. 8. I found no evidence to confirm this deportation (but I did not work in St. Petersburg archives), and Gelb also doubts that an ethnically targeted deportation took place. Gelb, "Western Finnic Minorities" (n. 9 above), pp. 238-42.

${ }^{155}$ GARF 3316/64/1284 (1932); Iwanow (n. 9 above), pp. 128-38.

${ }^{156}$ See GARF 3316/64/1078 (1931): 1-4, 20-53, 76-77; GARF 374/27s/1076 (1929): 59-63; A. Nugis, Protiv velikoderzhavnogo shovinizma i mestnogo natsionalizma (Khabarovsk, 1933), pp. 26-28; GARF 3316/64/1078 (1931): 5ob; Agi Zakir, "Zemelnaia politika v kolkhoznom dvizhenii sredi koreitsev dal'no-vostochnogo kraia," Revoliutsiia i natsional'nosti, nos. 2-3 (1931): 76-81.

${ }^{157}$ GARF 374/27s/1706 (1929): 40ob.

${ }^{158}$ Haruki Wada, "Koreans in the Soviet Far East, 1917-1937," in Koreans in the Soviet Union, ed. Daac-Sook Suh (Honolulu, 1987), p. 40.

${ }^{159}$ GARF 3316/16a/384 (1928): 1-2.

${ }^{160}$ GARF 5446/15a/258 (1933): 41-42.

${ }^{161}$ GARF 374/27s/1706 (1929): 8ob.

162 GARF 1235/141/359 (1929): 3. 
likewise threatened, showing that even Korean Soviet officials were suspect. ${ }^{163}$ The deportation was scheduled to begin in 1930. Ten thousand Koreans were to be moved northward and 10,000 demobilized Red Army soldiers and their families were to be settled in the Far Eastern border zones. ${ }^{164}$ In reality, only 1,342 Koreans were actually resettled in 1930, "including 431 resettled by force (prinuditel'nym sposobom)." ${ }^{165}$ In 1931, the plan was officially abandoned. ${ }^{166}$ In the end, only five hundred Korean families (about 2,500 individuals) had been resettled. ${ }^{167}$ It appears that the Foreign Ministry's concerns that Japan could use the deportation of Japanese subjects from the Soviet border regions as a casus belli led to the abandonment of Korean resettlement. ${ }^{168}$

In both the west and east, then, the Soviet government retreated from largescale ethnic cleansing as the collectivization emergency subsided. However, the effects of this crisis were felt in a greatly intensified regime of control in the border regions. By 1929, the term "border regions" had been expanded to include not only all raiony touching the Soviet border (called the primary border zone) but also all raiony touching those border raiony (the secondary border zone). ${ }^{169}$ In Ukraine alone, this included a population of about 2-3 million. ${ }^{170}$ In keeping with the new militant rhetoric, border raiony were now often referred to as "front"(frontovye) raiony in opposition to nonborder "rear" (tylovye) raiony. ${ }^{171}$ Each year likewise witnessed an increase in the size of the OGPU's border guard. ${ }^{172}$ Deportations of "active counter-revolutionary and kulak elements" from the border regions intensified. ${ }^{173}$ A further innovation begun during collectivization was the formation of Red Army collective farms in the border regions. Ambitious plans were drawn up to settle tens of thousands of demobilized Red Army soldiers in the Far East's border regions, though only about 10,000 were actually settled before the endeavor was temporarily abandoned in 1933, only to be revived when the next wave of ethnic cleansing

${ }^{163}$ Ibid.,pp. 3-4.

${ }^{164}$ GARF 1235/141/1356 (1930): 18-19, 3316/64/1078 (1931): 83; Rossiiskii Gosudarstvennyi Arkhiv Ekonomiki (RGAE) 7486/42s/5 (1931): 113.

${ }^{165}$ GARF 1235/141/1356 (1930): 18-19.

${ }^{166}$ Ibid., pp. 18-20; RTsKhIDNI 17/3/777 (30.02.30): 118/8, 17/3/813 (15.02.31): 26/32.

${ }^{167}$ GARF 3316/64/1078 (1931): 83.

${ }^{168}$ GARF 5446/29/67 (1937): 18.

${ }^{169}$ GARF 393/1s/283 (1929): 1 .

170 TsDAHOU 1/16/8 (16.01.32): 167-73.

${ }^{171}$ RTsKhIDNI 62/1/829 (10.03.31): 33 .

${ }^{172}$ RTsKhIDNI 17/162/8 (20.04.30): 124/80, 17/162/11 (01.12.31): 78/80,(27.02.32): 90/45; 17/162/12 (16.04.32): 96/21.

${ }^{173}$ TsDAHOU 1/16/8 (08.01.32): 136, 1/16/35 (21.03.31): 16; RTsKhIDNI 17/162/8 (20.04.30): 124/80, 17/162/14 (19.04.33): 136/94; "Spetspereselentsy-zhertvy 'sploshnoi kollektivizatsii,", Istoricheskii arkhiv, no. 4 (1994), p. 156. 
swept through the Far East in 1937. ${ }^{174}$ Red Army collective farms emerged as part of the 1928 Korean deportation plan and would consistently accompany Soviet ethnic cleansing. If national territories in the border regions were the symbol of the Piedmont Principle, Red Army collective farms became the symbol of Soviet xenophobia.

\section{The UkRAINIAN CRISIS}

Collectivization and the accompanying emigration movement focused Soviet xenophobia on the Soviet Union's diaspora nationalities-Germans, Poles, Koreans - whose flight was felt to have demonstrated greater loyalty to their foreign homelands than to the Soviet Union. Their actions naturally undermined the viability of the Piedmont Principle and exacerbated Soviet xenophobia. However, the diaspora nationalities were of little importance to domestic Soviet nationalities policy and of less importance to Soviet foreign policy ambitions than large border republics such as Ukraine and Belorussia, whose cross-border ethnic ties were key to the Soviet goal of undermining Polish rule in Poland's majority Ukrainian and Belorussian territories. The Ukrainian crisis, which climaxed in 1932-33, would cast doubts on these cross-border ethnic ties as well, and so lead to a complete abandonment of the Piedmont Principle.

In the 1920s, Ukraine was the site of extremely aggressive efforts to implement the policy of Ukrainization, which involved establishing Ukrainian as the republic's official language of government and the promotion of ethnic Ukrainians into positions of leadership in government, education, and industry. ${ }^{175}$ This program's primary goal was domestic: to disarm Ukrainian nationalism by granting the forms of Ukrainian nationhood. However, it also served the important foreign policy goal of making Soviet Ukraine attractive to the crossborder Ukrainian population in Poland - in the words of a prominent Ukrainian Communist, of turning Soviet Ukraine into "a center of attraction for the mass of discontented Ukrainians [in Poland]." 176 This ambition succeeded spectacularly. By the mid-1920s, Soviet Ukraine had become broadly popular in Polish Ukraine. The Piedmont Principle was working. An autonomous Communist Party of western Ukraine had been formed to exploit this seditious po-

${ }^{174}$ RGAE 7486/42s/8 (1932): 42-55; 7486/42s/5 (1931): 113; GARF 5446/15a/262 (1934): 20; 5446/15a/258 (1933): 41-42.

${ }^{175}$ George O. Liber, Soviet Nationality Policy, Urban Growth, and Identity Change in the Ukrainian SSR, 1923-1934 (Cambridge, 1992); Martin, "An Affirmative Action Empire" (n. 13 above), pp. 63-173.

${ }^{176}$ RTsKhIDNI 17/69/58 (1927): 166. 
tential. ${ }^{177}$ In December 1924, in a further appeal to Ukrainian national sentiment, the Comintern promised the eventual annexation of all majority Ukrainian territory to Soviet Ukraine. ${ }^{178}$

However, as with collectivization and the emigration movement, the Piedmont Principle became enmeshed with a domestic political crisis. In April 1926, a prominent Ukrainian Communist, Oleksandr Shumskyi, attacked Ukraine's first party secretary, Lazar Kaganovich, for failing to implement Ukrainization decisively. ${ }^{179}$ Stalin supported Kaganovich and, after nine months of maneuvering, Shumskyi was publicly denounced as a Ukrainian nationalist and transferred to a provincial Russian city. Such incidents were not uncommon in the 1920s and the "Shumskyi Affair" would have been of limited political significance were it not for the Piedmont Principle. The Shumskyi Affair was suddenly internationalized when the leadership of the West Ukrainian Communist Party voted unanimously to defend Shumskyi and denounce Kaganovich as a Great Russian chauvinist. ${ }^{180}$ Their action provoked a furious polemic between the sister Ukrainian parties, which finally resulted in the Comintern's excommunication of the entire leadership of the West Ukrainian Communist Party. This outcome was an enormous embarrassment for the Comintern and the Soviet leadership. ${ }^{181}$

Still, it might have remained only an embarrassment had it not also coincided with the height of the 1927 war scare. Marshall Pilsudski's coup d'etat in Poland in May 1926 was interpreted by the Soviet leadership as the first step in an imminent attack by world imperialism on the Soviet Union. ${ }^{182}$ After his successful coup, Pilsudski launched a well-publicized attempt to improve relations with Poland's Ukrainian population. ${ }^{183}$ These efforts were interpreted in the Soviet Union as an ominous attempt by "international and especially English imperialism ... along with Polish fascism ... to turn Western Ukraine into a bridgehead for an attack on Soviet Ukraine." ${ }^{184}$ The defection of the West Ukrainian Communist leadership was assimilated into this sinister sce-

${ }_{177}$ Janusz Radziejowski, The Communist Party of Western Ukraine, 1919-1929 (Edmonton, 1983).

${ }^{178}$ Skrypnyk, Statti i promovy. Tom II (n. 97 above), pp. 404-19. The decree promised the same for Soviet Belorussia.

179 James E. Mace, Communism and the Dilemmas of National Liberation: National Communism in Soviet Ukraine, 1918-1933 (Cambridge, Mass., 1983); Martin, "An Affirmative Action Empire," pp. 312-54.

${ }^{180}$ Radziejowski, pp. 127-31.

${ }^{181}$ Mykola Skrypnyk, Dzherela ta prychyny rozlamu $v$ KPZU (Kharkov, 1928).

182 Jon Jacobson, When the Soviet Union Entered World Politics (Berkeley, Calif., 1994), pp. 206-32.

${ }^{183}$ Radziejowski, pp. 94-96.

${ }^{184}$ Skrypnyk, Dzherela ta prychyny, p. 124. 
nario. One Ukrainian Communist leader noted with alarm that, "due to the clever policy of Pilsudski," western Ukraine was being turned into a "Piedmont to attract discontented elements within [Soviet] Ukraine." ${ }^{185}$ In other words, the tables had been turned. The Piedmont Principle was now being used against the Soviet Union.

Remarkably, the Piedmont Principle was also being used by the Soviet Ukrainian leadership to make territorial claims within the Soviet Union. Throughout the 1920s, the Ukrainian leadership claimed majority Ukrainian territory not only from Poland, which of course was perfectly acceptable, but also from the Russian federal republic (RSFSR). ${ }^{186}$ For instance, Skrypnyk cited the December 1924 Comintern resolution, which advocated the eventual annexation of Polish Ukraine, to claim neighboring majority Ukrainian regions from the RSFSR. ${ }^{187}$ The Piedmont Principle, in his opinion, worked in both directions. It authorized territorial claims against both capitalist Poland and Soviet Russia. While Ukraine's territorial claims on the RSFSR were mostly rejected, a compromise solution led to the formation of about 130 Ukrainian national regions and 4,000 Ukrainian townships in the RSFSR. ${ }^{188}$ This policy was deeply resented by local Russian officials, who understandably saw it as a prelude to the eventual annexation of their territory by Ukraine. It also intensified central suspicions as to the loyalty of the Ukrainian Communists.

These suspicions surfaced dramatically during the grain requisitions crisis of 1932-33. The 1932 Soviet harvest was insufficient to feed the country. Confronted with this situation, Stalin decided to extract as much grain as possible from the peasantry in order to feed the cities. This meant the famine would be concentrated in the Soviet Union's grain-growing regions. The two regions that failed most conspicuously to fulfill the resulting onerous grain requisitions were Ukraine and the North Caucasus. Stalin interpreted these failures as political resistance. With regard to Ukraine, on August 11, 1932, he wrote Kaganovich:

The most important thing now is Ukraine. Things in Ukraine are bad. They're bad in the Party. They say that in two Ukrainian oblasts (I believe Kiev and Dneprepetrovsk) around 50 raikomy have spoken out against the grain requisitions plan, declaring it unrealistic. In other raikomy, it appears things are no better. What is this like? It's not a party, but a parliament, a caricature of a parliament ...

If we don't take measures now to correct the situation in Ukraine, we may lose

${ }^{185}$ RTsKhIDNI 17/69/58 (1927): 167.

${ }^{186}$ For an account of this campaign, see Martin, “An Affirmative Action Empire," pp. 566-82.

${ }^{187}$ Skrypnyk, “Zlikviduvaty liuksemburgiianstvo," in (1925) Statti i promovy, pp. 7576. In 1928, Skrypnyk even tried to get Comintern backing for his position. M. Skrypnyk, Natsional'nyi vopros v programme kominterna (Kharkov, 1929), pp. 35-37.

${ }^{188}$ Martin, "An Affirmative Action Empire" (n. 13 above), p. 605. 
Ukraine. Keep in mind that Pilsudski is not sleeping, and his agents in Ukraine are many times stronger than [Ukrainian GPU head] Redens and [Ukrainian First Party Secretary] Kosior think. Keep in mind that in the Ukrainian Communist Party (500 thousand members, ha-ha) there are not a few (yes, not a few) rotten elements, conscious and subconscious Petliurites, and finally - direct agents of Pilsudski. As soon as things worsen, these elements will not hesitate to open fire within (and without) the Party, against the Party. ${ }^{189}$

Stalin then suggested a few changes needed to turn Ukraine into "a true fortress of the USSR," and he again concluded that "without these changes, ... I repeat, we may lose Ukraine." ${ }^{190}$ Here again domestic political difficulties immediately became enmeshed with foreign-policy concerns. In Stalin's view, the Piedmont Principle was again being reversed. The Ukrainian Communist Party was not leading western Ukraine but had itself fallen under the influence of west Ukrainian nationalism (the Petliurites) and their foreign patron, Marshal Pilsudski, with his long-standing irredentist ambitions in Ukraine.

This suspicion of cross-border Ukrainian influence was soon extended to the North Caucasus as well. In October 1932, the Politburo sent a commission headed by Kaganovich to the North Caucasus to enforce the center's grain collections quota. On his arrival, Kaganovich blamed lax local Communist leadership for the region's failure to fulfill its quota, but he also cited sabotage by "organized groups among those arriving from Ukraine, especially in the Kuban where Ukrainian is spoken." ${ }^{191}$ Kaganovich focused his commission's punitive efforts on the Kuban region. ${ }^{192}$ Moreover, after Kaganovich's return to Moscow, on December 14, 1932, the Politburo issued a decree that officially linked the failure of grain requisitions in both Ukraine and the North Caucasus to Ukrainian nationalist resistance and the policy of Ukrainization. Within Ukraine itself, "Ukrainization was carried out mechanically, without considering the specifics of each region, without a careful choice of Bolshevik Ukrainian cadres. This made it easy for bourgeois-nationalist elements, Petliurites and others to create a legal cover for their counter-revolutionary cells and organizations." 193 Within the North Caucasus, "the light-headed, non-Bolshevik 'Ukrainization' of almost half the North Caucasus districts did not serve the cultural interests of the population and, with the total absence of surveillance by North Caucasus

${ }^{189}$ RTsKhIDNI 81/3/99 (1932): 145-48.

${ }^{190}$ Ibid.,p. 150.

${ }^{191}$ RTsKhIDNI 81/3/214 (1932): 4.

${ }^{192}$ Nobuo Shimotomai, "A Note on the Kuban Affair (1932-1933)," Acta Slavica Iaponica, no. 1 (1983), pp. 39-56; E. N. Oskolkov, Golod 1932/1933: Khlebozagotovki $i$ golod 1932/1933 goda v severo-kavkazskom krae (Rostov-na-donu, 1991); Martin, "An Affirmative Action Empire," pp. 606-32.

${ }^{193}$ Holod 1932-1933 rokiv na Ukriani: ochyma istorykiv, movoiu dokumentiv (Kiev, 1990), p. 121. 
organs of the Ukrainization of schools and the press, gave a legal form to the enemies of Soviet power for the organization of opposition to Soviet power by kulaks, officers, re-emigrated Cossacks, members of the Kubanskyi Rad, and so forth." ${ }^{194}$ Ukrainian nationalism, then, was blamed for the failure of grain requisitions in both Ukraine and the North Caucasus. Moreover, in each region, the influence of cross-border ethnic ties in the form of returned Cossack emigres and west Ukrainian Petliurites was highlighted.

The pernicious role of cross-border ethnic influence was a major propaganda theme in the 1933 Ukrainian terror, during which tens of thousands of putative Ukrainian nationalists were arrested for allegedly conspiring with the new Nazi leadership in Germany to separate Ukraine from the Soviet Union. ${ }^{195}$ The major target for, arrest during this campaign was the diaspora community of west Ukrainian emigres. ${ }^{196}$ For the first time, ethnic Germans and Poles (both Soviet citizens and noncitizens) were likewise targeted. ${ }^{197}$ The Piedmont Principle was now irrevocably abandoned. With the rise of fascist and authoritarian regimes throughout east central Europe, official Soviet propaganda, adopting the phrase from Stalin's letter to Kaganovich, now instead emphasized turning Ukraine - and, indeed, the entire Soviet Union - into a "fortress" against all foreign influence.

\section{Ethnic Cleansing}

The Ukrainian crisis not only marked the final abandonment of the Piedmont Principle; it also led to a mass deportation that was at least partially ethnic. The December 14 Politburo decree ordered the deportation of the entire Kuban Cossack town of Poltava for "the sabotage of grain delivery." 198 In the next month, another two Cossack towns were deported; ultimately, a total of approximately 60,000 Kuban Cossacks were deported for failing to meet their grain requisitions. ${ }^{199}$ Following the emerging Soviet norm, the Cossacks were replaced with 14,090 Red Army soldiers and their families. ${ }^{200}$ The Cossacks were officially deported for "kulak" sabotage, but the deportation of kulaks

${ }^{194}$ Ibid.,pp. 292-93.

${ }^{195}$ S. Kosior, Itogi i blizhaishie zadachi provedeniia natsional'noi politiki na Ukraine (Kharkov, 1933).

${ }^{196}$ O. S. Rublov and A. Iu. Cherchenko, Stalinshchyna i dolia zakhidnoukrains'koi intelihentsii.20-50-ti roku XX st. (Kiev, 1994).

${ }^{197}$ Piotr Mitzner, “Widmo POW,' Karta, no. 11 (1993), pp. 21-23; Iwanov (n. 9 above), pp. 351-56; GARF 1235/128/3 (1933): 216-17.

${ }^{198}$ Holod 1932-1933 rokiv, p. 293.

${ }^{199}$ Oskolkov, pp. 55-60; RGVA 9/36/613 (1933): 6, 46.

${ }^{200}$ RGAE 5675/1/33 (1933): 19. 
had never involved entire villages. In one sense, these deportations marked a repetition of the soslovie-based deportation of the Terek Cossacks in 1920-21, a parallel raised by Kaganovich himself in November 1932: "All the Kuban Cossacks must be reminded how in 1921 the Terek Cossacks were deported. It's the same situation now." ${ }^{201}$ However, the Kuban Cossacks were also labeled as Ukrainian nationalists and therefore the deportations took on a new ethnic dimension. The Kuban Cossack deportation, in fact, marked a transition from class-based deportations, which predominated prior to 1933, to the ethnic deportations that predominated from 1933 to 1953.

These ethnic deportations began in the western border regions in 1935. The targets were diaspora nationalities - that is, national minorities (such as Poles, Germans, Finns) with cross-border ethnic ties to a foreign nation-state. As we have seen, the Soviet leadership had already sanctioned ethnic resettlement in the 1920s. Also, the diaspora nationalities were subject to considerable popular ethnic hostility, which led to harsh treatment during collectivization and the resulting emigration movements that in turn raised concern about their loyalty. These concerns escalated in 1933-34, when a campaign was launched in Germany to help their starving German "Brothers in Need" in the Soviet Union by sending tens of thousands of food packets and foreign currency remittances (called "Hitler help" by the Soviets). ${ }^{202}$ This campaign provided further evidence that the diaspora nationalities could be used by foreign governments as weapons against the Soviet Union. The 1932-33 Ukrainian crisis not only discredited the Piedmont Principle but also greatly intensified Soviet concerns over cross-border ethnic ties. Finally, the rise of Hitler and the German-Polish nonaggression pact of January 1934 focused Soviet xenophobia on the western border regions. ${ }^{203}$

In 1934, the Soviet government undertook a reevaluation of its policy toward its Polish population and an intensification of its regime for the western border regions. The Polish investigation found "an incorrect policy and practice of introducing Polish schools into raiony and villages with a majority Belorussian population and the compulsory instruction in Polish for Belorussian children." ${ }^{204}$ The head of the Belorussian government, N. M. Goloded, gave this discovery a new sinister interpretation:

${ }^{201}$ Oskolkov, p. 52.

${ }^{202}$ Buchsweiler (n. 126 above), pp. 64-71; CGM reel 5213 (25.05.32): K481339-41 (06.06.32): K481348-50; Nimtsi v Ukraini 20-30-ti rr. XX st. (Kiev, 1994): 179-85.

${ }^{203}$ Jonathan Haslam, The Soviet Union and the Struggle for Collective Security in Europe, 1933-1939 (New York, 1984), p. 36.

${ }^{204}$ RTsKhIDNI 17/21/404 (03.08.34): 2, 18-21. Belorussian-speaking Catholics often considered themselves Poles and demanded Polish education for their children, a practice considered legitimate prior to 1934 . 
We forgot that with the formation of a Polish national raion our task becomes considerably more difficult. The enemy also exploits this act of Soviet power. Do you really think that the defense and other organs of Poland did not take into consideration this act of Soviet power? They did and they acted - it can't be excluded that - in a closed plenum we can speak of this - that Polish organs may have specially worked on the Polonization of [our] schools ... the possibility can't be excluded that special work was undertaken to Polonize the Belorussian population through these schools. The possibility can't be excluded that here we see an attempt by Polish fascism to build something for future contingencies. ${ }^{205}$

This statement represented a fundamental shift, for it sanctioned the view that Polish national institutions had fostered rather than disarmed nationalism, an interpretation that would justify both the abolition of national institutions and the onset of ethnic cleansing. In the fall of 1934, the Politburo also formulated a new regime for its western border regions. ${ }^{206}$ This regime created yet another border category, the "forbidden border zone" (zapretnyi pogranichnyi zon), into which no one could enter without special NKVD permission. ${ }^{207}$ This zone was officially only 7.5 kilometers deep, but in Leningrad it ran as deep as ninety kilometers along the Latvian and Estonian borders. ${ }^{208}$ A variety of security measures accompanied this decree. One of them was ethnic cleansing. ${ }^{209}$

Between February 20 and March 10, 1935, a total of 8,329 families (about 41,650 individuals) were deported from the border regions of Kiev and Vinnitsya oblasts to eastern Ukraine. Although Germans and Poles made up only a few percent of the local population, they represented 57.3 percent of the deportees. ${ }^{210}$ This limited initial action against "unreliable" elements was expanded in the course of 1935. In July 1935, Kiev officials wrote the Ukrainian Central Committee that "the number of households deported and resettled had not completely cleansed (ochistit') the Markhlevskii [Polish] raion of antiSoviet elements." 211 They asked for and received permission to deport three hundred additional Polish households. ${ }^{212}$ In October 1935, the Ukrainian TsK petitioned Moscow for permission to deport still another 1,500 Polish households. ${ }^{213}$ In response, NKVD chairman Genrikh Iagoda wrote Molotov that the spring deportations had "significantly cleansed (ochistilo) the border regions, especially Kiev oblast, from counter-revolutionary nationalist (Polish and Ger-

${ }^{205}$ Ibid., pp. 87-88.

${ }^{206}$ RTsKhIDNI 77/1/425 (1934): 1 .

${ }^{207}$ TsDAHOU 1/16/13 (26.08.36): 104-9; SZ (17.07.35): 45/377.

${ }^{208}$ Leningradskaia pravda, no. 113 (23.05.35): 1; BFORC reel 3 (03.06.35), vol. 19454,pp. 171-74.

${ }^{209}$ TsDAHOU 1/16/11 (20.12.34): 316-17, 1/16/12 (23.01.35): 39.

${ }^{210}$ 2,866 Polish and 1,903 German families. See GARF 5446/16a/265 (1935): 14.

${ }^{211}$ TsDAHOU 1/6/396 (17.08.35): 46/30, 166.

${ }^{212}$ Ibid., pp. 166-67; TsDAHOU 1/16/12 (05.09.35): 267-68.

${ }^{213}$ TsDAHOU 1/16/12 (16.10.35): 314. 
man) and anti-Soviet elements ... [but] in the border regions of Vinnitsya oblast there remain significant cadres of counter-revolutionary Polish nationalist elements." ${ }^{214}$ The charge of counterrevolution and the language of ethnic cleansing had now fully emerged.

In January 1936, before this third deportation had even been completed, the order was given for a massive new deportation of 15,000 German and Polish households, now to Kazakhstan rather than eastern Ukraine. ${ }^{215}$ In Kazakhstan, they were quickly reduced to the same status as the formerly deported kulaks. ${ }^{216}$ These deportations, however, still remained partial. Not all Germans and Poles were labeled counterrevolutionary and deported. The deportations of 1935-36 included approximately half the German and Polish population of the Ukrainian border regions. ${ }^{217}$ No one outside the border regions was deported. However, the Germans and Poles who remained in Ukraine saw a gradual abolition of their national institutions. ${ }^{218}$

Ethnic cleansing in Leningrad oblast followed the Ukrainian pattern closely. A large deportation, authorized by Iagoda on March 25, 1935, targeted the small Estonian and Latvian and larger Finnish population of the Leningrad border regions. ${ }^{219}$ According to Finnish sources, about 7,000-9,000 Finns were deported to Siberia and Central Asia. ${ }^{220}$ As in Ukraine, this first deportation targeted independent peasants, lishentsy, and other stigmatized categories. ${ }^{221}$ However, again following the Ukrainian pattern, in the spring of 1936 a second larger deportation of about 20,000 Finnish peasants to Siberia took place. ${ }^{22}$

${ }^{214}$ GARF 5446/16a/265 (1935): 14-15.

${ }^{215}$ GARF 5446/18a/209 (1936): 1; TsDAHOU 1/16/12 (25.11.35): 346, 1/16/13 (15.03.36): 25; RTsKhIDNI 17/42/186 (16.02.35): 6-10; 17/42/208 (31.03.36): 15 .

${ }^{216}$ Initially, the deported were not formally deprived of their civil rights but were, like the kulaks, settled in NKVD work settlements (trudposelki). Later they were formally reduced to the existing kulak status of spetspereselentsy. GARF 5446/18a/209 (1936): 30, 70-73; Nikolaj F. Bugaj, “'Specjalna teczka Stalina': Deportacje i reemigracja polakow,” Zeszyty Historyczie, no. 107 (1993), pp. 137-38.

${ }^{217}$ This is an approximation based on the 1926 census. By 1941, 70-80 percent of the Germans had been deported from the German Pulinskii raion. Buchsweiler (n. 126 above), p. 157.

${ }^{218}$ B. V. Shyrko, “'Shkidnytstvo riznykh natsii,” Arkhivy Ukrainy, no. 4 (1992), pp. 32-40; Martin, "An Affirmative Action Empire" (n. 13 above), pp. 757-59.

${ }^{219}$ BFORC reel 3 (1935), vol. 19453, pp. 259-64, vol. 19454,pp. 171-74; BFORC reel 5 (1936), vol. 20349, p. 169, reel 6 (1936), vol. 20353, pp. 14-17; The Ingrian Committee (n. 154 above), pp. 12-14; Gelb, "Western Finnic Minorities" (n. 9 above), pp. 242-44; N. F. Bugai, Iosif Stalin-Lavrentiiu Berii: "Ikh nado deportirovat'” (Moscow, 1992), p. 20. Iagoda had approved the deportation of 3,547 families, not all of whom were Finns.

${ }^{220}$ The Ingrian Committee, p. 14.

${ }^{221}$ BFORC reel 6 (1936), vol. 20353, p. 16.

${ }^{222}$ Manley, p. 9. BFORC reel 16 (29.07.36), vol. 20353, pp. 14-17; Gelb, "Western Finnic Minorities," p. 243. 
Still, not all Finns were deported. The removal of 30,000 Finns amounted to about 30 percent of the Leningrad Finnish population. ${ }^{223}$ The deportations were accompanied, again as in Ukraine, by an abolition of many national institutions. ${ }^{224}$

The novel factor in Leningrad oblast was that the city of Leningrad itself lay within the forbidden border zone. ${ }^{225}$ The mass arrests and deportation of unreliable elements from Leningrad in late 1934, following the murder of Kirov, was actually part of the new border regime and had been planned prior to Kirov's murder. In a reply to an angry letter by Academic Pavlov protesting this repression, Molotov made clear this connection: "In Leningrad special measures are being taken against malicious anti-Soviet elements, which is tied to the special border position of this city." ${ }^{226}$ Again, major targets of this wave of repressions were the western national minorities: Finns, Latvians, Estonians, Germans, Poles. ${ }^{227}$

By 1936, then, the Soviet Union's western diaspora nationalities had been stigmatized as collectively disloyal and subjected to ethnic cleansing. In the Far East, although Koreans had been threatened with deportation already in 1926, ethnic cleansing was delayed. There was a major wave of Korean arrests in $1935 .{ }^{228}$ In July 1936, the Far Eastern kraikom first petitioned Sovnarkom for permission to implement the new border regime in the Far East, in order to frustrate "the aggressive tactics of the local authorities in Manchuria and the Japanese, who exploit every border crossing from our side, either to recruit spies and saboteurs or to make various accusations against the Soviet Union." ${ }^{229}$ This appeal to Soviet xenophobia was opposed by Maxim Litvinov, who noted that the Portsmouth Treaty forbade "military measures on the Korean border." ${ }^{230}$ At this point, the need to placate the Japanese outweighed concern over Japanese influence on the Korean population of the Far East border

${ }^{223}$ Matley (n. 9 above), pp. 8-10.

${ }^{224}$ GARF 3316/30/825 (1937); BFORC reel 6 (29.07.36), vol. 20352,p. 24.

${ }^{225}$ One did not need NKVD permission to enter Leningrad, only to reside in it.

226 “ 'Poshchadite zhe Rodinu i Nas'. Protesty akademika I. P. Pavlova protiv bol'shevistskikh nasilii," Istochnik, no. 1 (1995), p. 143 (letter from Molotov to Pavlov, March 15, 1935).

${ }^{227}$ BFORC reel 5 (31.01.36), vol.20349,pp. 169-70. The special suspicion against Soviet western national minorities is nicely illustrated by an informant of the British consul, who related that ballet dancers who socialized with the German consul were told to stop: "When they enquired who were the foreigners whom they were to avoid, they were told members of the German, Finnish, Estonian, Latvian, and Polish consulates." BFORC reel 5 (31.01.36), vol. 20349, p. 169.

228 "Koreitsy," Tak eto bylo, vol. 1 (Moscow, 1993), pp. 47-84; Gelb, "An Early Soviet" (n. 9 above), p. 397.

${ }^{229}$ GARF 5446/29/67 (1936): 42-43.

${ }^{230}$ Ibid., p. 18. 
regions. Only on July 28, 1937, after interventions by Ezhov and Voroshilov, was the Foreign Ministry forced to accept the introduction of the new border regions' regime in the Far East. ${ }^{231}$

On August 18, 1937, Stalin and Molotov sent a draft proposal for a Korean deportation to the Far Eastern leadership. ${ }^{232}$ This proposal was similar to the 1935 deportations in Ukraine and Leningrad oblast in that the deportation was confined to twelve border raiony, but it was distinct in that it targeted only Koreans, and all Koreans were to be deported. Three days later, the official TsK and Sovnarkom deportation decree was expanded to include twenty-three raiony, which increased the number of Koreans to be deported from 44,023 to 135,343. ${ }^{233}$ Demobilized Red Army soldiers were also to be settled in formerly Korean collective farms. ${ }^{234}$ The scope of the deportation continued to expand until finally, on September 22, 1937, the assistant head of the NKVD, V. V. Chernyshev, asked Ezhov for the right to deport every last Korean from the Far Eastern krai. His reasoning was highly revealing: "To leave these few thousand Koreans in the Far Eastern krai, when the majority have been deported, will be dangerous, since the family ties of all Koreans are very strong. The territorial restrictions on those remaining in the Far East will undoubtedly affect their mood and these groups will become rich soil for the Japanese to work on." 235 In other words, we have injured some Koreans, and therefore we can assume all Koreans are now our enemies. This psychology is extremely important not just for the spread of ethnic cleansing but also for the ratcheting up of all Soviet terror. Chernyshev's request was approved. ${ }^{236}$ By October 29, Ezhov could report to Molotov that 171,781 Koreans had been deported to Kazakhstan and Uzbekistan. ${ }^{237}$ The first ethnic cleansing of an entire nationality, including Communists, had been accomplished.

When the kolkhoznik Kim-Sen-Men was told that all Koreans were being deported to central Asia, he responded that "in all likelihood, they will create for us a Korean Autonomous Oblast there." ${ }^{238}$ Kim's comment was as revealing as Chernyshev's, for it illustrated the continuity between the 1920 s policy of ethnically based agricultural resettlement and the 1930s policy of ethnic

${ }^{231}$ GARF 5446/29/67 (1937): 18-25.

${ }^{232}$ RGVA 33879/2/181 (1938): 8-11.

${ }^{233}$ Belaia kniga, 64-67; RGVA 33879/2/181 (1937): 3-6.

${ }^{234}$ GARF 5446/29/113 (1938).

${ }^{235}$ Belaia kniga (n. 49 above), pp. 85-86, 88, 109-110.

${ }^{236}$ Ibid.,p. 111.

${ }^{237}$ GARF 5446/29/48 (1937): 156. He noted that seven hundred dispersed Koreans remained to be rounded up. Approximately 11,000 Chinese were also deported with the Koreans, as were six hundred Poles, and several hundred Germans, Latvians, and Lithuanians were arrested. Nikolai F. Bugai, "Koreiskii vopros' na dal'nem vostoke i deportatsiia 1937 goda," Problemy dal'nego vostoka, no. 4 (1992), p. 158.

${ }^{238}$ Belaia kniga, p. 133. 
cleansing. Surprisingly, Kim was not entirely mistaken. The deported Koreans were settled in separate Korean collective farms. ${ }^{239}$ Korean-language schools were formed. ${ }^{240}$ Ezhov himself authorized the transfer of an entire Korean pedagogical school, a Korean publishing house, and a Korean newspaper to central Asia. ${ }^{241}$ Even in the midst of 100 percent ethnic cleansing, where every Korean had been declared a potential spy and traitor, the formulas of the Soviet nationalities policy could still not be entirely abandoned.

\section{ENEMY NATIONS}

The Korean deportation took place at the onset of the mass operations of the Great Terror, which helps explain why that deportation spread so quickly to become a total deportation of all Koreans. The Great Terror witnessed the culmination of a gradual shift from predominantly class-based terror to terror that targeted (among others) entire nations. At this time, the duality that allowed for the simultaneous deportation of all Koreans and the formation of new national institutions in their place of exile was finally resolved. At the 1937 Ukrainian party congress, Oleksandr Shlikhter, an ideology specialist, spoke of the "wrecking of various nations" (shkidnytstvo riznykh natsii) in reference to the Germans and Poles of Ukraine. ${ }^{242}$ Few others were so blunt in such a relatively public forum, but this sentiment underlay a new internal party discourse that justified collective terror against the Soviet Union's diaspora nationalities.

The Great Terror saw an extension of ethnic cleansing to all the Soviet border regions and all of the Soviet Union's diaspora nationalities. On July 17, 1937, Sovnarkom issued a decree extending the new border regions' regime to territory bordering on Iran and Afghanistan. The new regime included ethnic cleansing: the deportation of over 1,000 Kurdish families in late 1937 and 2,000 Iranian families in $1938 .{ }^{243}$ By the end of 1938, the new regime had been extended along the entire Soviet border. ${ }^{244}$ There were also further ethnic deportations from the western border regions. In November 1937, the Odessa

${ }^{239}$ GARF 5446/29/48 (1937): 156.

${ }^{240}$ Ibid.,p. 176.

${ }^{241}$ Belaia kniga, p. 100; GARF 5446/20a/509 (1937): 1-12.

${ }^{242}$ Nimtsi $v$ Ukraini (n. 202 above), p. 13.

${ }^{243}$ GARF 5446/20a/933 (1937): 7-8, 5446/23a/50 (1938): 1-2; Nikolai F. Bugai, "Kanun voiny: Repressii v otnoshenii sovetskikh kurdov," in Sovetskie kurdy: Vremia peremen (Moscow, 1993), p. 48; "Kurdy," in Tak eto bylo, vol. 1, pp. 95-125; GARF 5446/ 23a/29 (1938): 23. "Iranian" was actually not an ethnic term, but one that embraced Persians, Azerbaijanis, and Kurds who originated in Iran (even if they were now Soviet citizens), again pointing to the key role of cross-border ethnic ties.

${ }^{244}$ GARF 5446/29/96 (1938): 1-10, and 5446/29/67 (1938): 52. 
obkom ordered the deportation of 5,000 German households. ${ }^{245}$ The decline in the German and Polish populations of Ukraine and Belorussia between the 1937 and 1939 censuses suggest there may have been other deportations as well. ${ }^{246}$

Most significantly, as ethnic cleansing spread outward to all the Soviet border regions, terror against diaspora nationalities also spread inward to embrace the entire Soviet Union. ${ }^{247}$ This process began with the anti-German and antiPolish campaigns during the 1933 Ukrainian terror. It took on all-union dimensions with the November 5, 1934, Politburo decree, "On the Battle with Counter-Revolutionary Fascist Elements in the German Colonies," which led to mass arrests and show trials not only in Ukraine but also in central territories such as the Slavgorod German raion in Siberia. ${ }^{248}$ Likewise, the Leningrad repressions following Kirov's murder targeted (among others) diaspora nationalities. In 1936, the Party Control Commission and the NKVD began a purge of all political emigres in the Soviet Union, with Poles as the primary focus, a purge that quickly escalated into mass arrests. ${ }^{249}$ With the onset of the Great Terror's "mass operations" in the summer of 1937, this elite terror against foreign Communists merged with the mass ethnic cleansing of domestic diaspora

${ }^{245}$ TsDAHOU 1/6/458 (19.11.37): 9/7,pp. 63-70.

${ }^{246}$ Ukraine's Polish population declined by approximately 90,000 individuals and its German population by 40,000 . In Belorussia, the Polish population declined from 119,881 in 1937 to 54,500 in 1939 (45.46 percent). Calculated (with adjustments for the inflated 1939 numbers) from Vsesoiuznaia perepis' naseleniia 1937 goda (Moscow, 1937), p. 94, and Vsesoiuznaia perepis' naseleniia 1939 goda (Moscow, 1939), p. 68. However, these population losses may reflect arrests and executions during the Great Terror rather than deportations.

${ }^{247}$ The terror did not target those stateless diasporas, whose coethnics did not live in concentrated communities adjacent to the Soviet Union, such as Jews, Assyrians, and Gypsies. Although they were treated with greater suspicion during the Great Terror, and some of their institutions were abolished, I have found no decrees specifically targeting them for repression. Nor have the statistics on the ethnic impact of the terror suggested they were targeted. According to Vaksberg, who had access to the former KGB archive in Moscow, the first specifically Jewish cases were initiated in 1939 after the Hitler-Stalin pact. Arkady Vaksberg, Stalin against the Jews (New York, 1994), pp. 80-102. See also Martin, "An Affirmative Action Empire" (n. 13 above), pp. 782-85.

${ }^{248}$ L. P. Belkovec, "Der Beginn des Massenterrors: Die Getreiderequirierung von 1934 im westsibirischen Deutschen Rayon," Forschungen zur Geschichte und Kultur der Russlanddeutschen, no. 4 (1994), p. 121; Victor Chentsov, "Die deutsche Bevolkerung am Dnepr im Zeichen des stalinistischen Terrors," Forschungen zur Geschichte und Kultur der Russlanddeutschen, no. 5 (1995), pp. 11-13; GARF 3316/30/831 (1936): 7-8, 3316/ 29/631 (1935): 18-19; Nimtsi v Ukraini, pp. 186-87.

${ }^{249}$ V. N. Khaustov, "Iz predystorii massovykh repressii protiv poliakov: Seredina 1930-kh gg," in Repressii protiv poliakov i pol'skikh grazhdan (Moscow, 1997), pp. 10-21; Nikita Pietrow, “Polska operacja NKWD," Karta, no. 11 (1993), pp. 24-27. 
nationalities to produce a mass terror campaign against the new category of enemy nations. ${ }^{250}$ On August 9, 1937, the Politburo confirmed NKVD decree 00485, "On the Liquidation of the Polish Sabotage-Espionage Group and the Organization POV (Pol'skoi organizatsii voiskovoi)." ${ }^{251}$ Two days later, Ezhov formally issued this decree (accompanied by a massive historical account of POV's origins and activities as justification of the anti-Polish operations), which identified targets for arrest: all Polish political emigres and refugees, as well as "the most active part of local anti-Soviet nationalist elements from Polish raiony." ${ }^{252}$ In October 1937, this category was extended to all Poles with "ties to [Polish] consuls" (konsul'skie sviazi), a category that could easily embrace any Soviet Pole. ${ }^{253}$ By 1938, the NKVD was arresting Poles (and other diaspora nationalities) exclusively based on their national identity. ${ }^{254}$

The August 11, 1937, POV decree served as the model for a series of NKVD decrees targeting all of the Soviet Union's diaspora nationalities. ${ }^{255}$ The NKVD referred to these decrees collectively as "the national operations" (to distinguish them from the other "mass operation" launched by NKVD decree 00447 on July 30, 1937, targeting "former kulaks, criminals, and other anti-Soviet elements"). ${ }^{256}$ A January 31, 1938, Politburo decree extended until April 15, 1938 , this "operation for the destruction of espionage and sabotage contingents made up of Poles, Latvians, Germans, Estonians, Finns, Greeks, Iranians, Kharbintsy, Chinese, and Romanians, both foreign subjects and Soviet citizens, according to the existing decrees of the NKVD." This decree also authorized a new operation "to destroy the Bulgarian and Macedonian cadres." 257

${ }^{250}$ There was also a July 25, 1937, NKVD decree, which targeted exclusively foreign Germans working in military plants or in transport. Leningradskii martirolog, 19371938, tom 2 (St. Petersburg, 1996), pp. 452-53.

251 "Massovye repressii opravdany byt' ne mogut," Istochnik, no. 1 (1995), p. 125. The decree is reproduced in Pietrow, pp. 27-29. POV was a real underground organization formed during World War I to support Pilsudski's legions. It ceased operations in Poland in 1918 and in Ukraine in 1921. Arrests by the NKVD for membership in POV began during the 1933 Ukrainian terror and continued through the Great Terror. Mitzner (n. 197 above), pp. 21-23.

${ }^{252}$ Both documents are reproduced in Iurii Shapoval, Volodymyr Prystaiko, and Vadym Zolotarov, eds., ChK-HPU-NKVD v Ukraini: Osoby, fakty, dokumenty (Kiev, 1997), pp. 347-77.

${ }^{253}$ N. V. Petrov and A. B. Roginskii, “'Polskaia operatsiia' NKVD 1937-1938 gg.,” in Represii protiv poliakov (n. 249 above), p. 27. "Konsul'skie sviazi" were also a standard arrest category in the other national operations. See Chentsov, p. 14.

${ }^{254}$ Petrov and Roginskii, pp. 29-34; Pietrow, p. 32; S. Bilokin, "Dokumenty z istorii NKVD URSR," Nashe mynule, no. 1 (1993), pp. 40-41.

${ }^{255}$ Petrov and Roginskii, pp. 28-29.

${ }^{256}$ Ibid., pp. 30-31. For decree 00447, see "Limity terroru," Karta, no. 11 (1993), pp. $8-15$.

${ }^{257}$ Tak eto bylo, vol. 1 (n. 228 above), p. 253. 
Koreans and Afghans too were targeted by NKVD decrees. ${ }^{258}$ The NKVD spoke of their "German operation" and "Latvian operation." 259 They arrested individuals "according to the Polish line" or "Finnish line" of the nationalities terror. ${ }^{260}$ Most revealingly, internal NKVD documents refer to their operations as directed against "nationalities of foreign governments," a designation for the diaspora nationalities - the vast majority of whom were Soviet citizens and whose ancestors had resided for decades in the Soviet Union and Russian empire - that absolutized their cross-border ethnic ties as the only salient aspect of their identity, sufficient proof of their disloyalty and sufficient justification for their arrest and execution. ${ }^{261}$

The national operations were not at all a minor part of the Great Terror. According to recently released statistics from the former KGB archive in Moscow, from July 1937 to November 1938 a total of 335,513 individuals were convicted in the national operations, while 767,397 were convicted in the operation carried out under decree 00447 (former kulaks, criminals, and other anti-Soviet elements). ${ }^{262} \mathrm{We}$ do not have an arrest total for this time period, but we do have a figure of 1,565,041 arrested on political charges between October 1, 1936, and November 1, 1938. Even using this extended time period, the national operations made up 21.4 percent and decree 00447 made up 49 percent of all arrests. When we examine total executions, the national operations assume a still larger role. Of the 681,692 executions in 1937-38, the national operations made up 247,157 (36.3 percent) and decree 00447 made up 386,798 (56.7 percent). Of all those arrested on political and nonpolitical charges in 1937-38, a total of 19 percent were executed; of those arrested under decree 00447 , a total of 49.3 percent were executed; of those arrested in the national operations, 73.7 percent were executed. The execution rate on the Polish operation was slightly higher (79.4 percent) and the Greek, Finnish, and Estonian operations even higher, while the Afghan and Iranian execution rates were much lower. ${ }^{263}$ To sum up, the national operations made up about a fifth of the total arrests and a third of the total executions during the Great Terror,

258 "Limity terroru," p. 8; Petrov and Roginskii, p. 33. In July 1937, Stalin authorized the arrest of all Afghan citizens in Turkmenistan. Tsentr Khraneniia Sovremennykh Dokumentov (hereafter TsKhSD) 89/48/7 (25.07.37): 1 .

${ }^{259}$ Rastsyslav Platonav and Mikola Stashkevich, "Dzve aperatsyi suprats' 'vorahav naroda,'” Belaruski histarychny chasopis, no. 1 (1993), pp. 78-79.

${ }^{260}$ Petrov and Roginskii, p. 28.

${ }^{261}$ Ibid.,p. 34.

${ }^{262}$ Unless otherwise noted, all statistics in the following two paragraphs are taken from ibid., pp. 32-33, 37-38; and Pietrow (n. 249 above), pp. 33, 39-40.

${ }^{263}$ This was the only information provided. The data follow the general pattern of greater severity in the west and lesser severity in the south. 
and arrest in the national operations was much more likely to result in execution. ${ }^{264}$

Unfortunately, we do not know exactly how many members of the diaspora nationalities were arrested or executed, since not everyone arrested in the Polish operation was a Pole, nor were all arrested Poles included in the Polish operation. For instance, through September 1, 1938, in Belorussia, Poles made up only 43 percent of those arrested in the Polish operation, Germans made up 76 percent of the German operation, and Latvians made up 74.6 percent of the Latvian operation. ${ }^{265}$ Moreover, all three nationalities were included in all three operations. In Moscow oblast, through July 1, 1938, Poles made up 57 percent of the Polish operation, and for the entire Soviet Union from September to November 1938 Poles made up 54.8 percent of the Polish operation. Roginskii and Petrov report that 139,835 individuals were arrested in the Polish operation, while 118,000-123,000 Poles were arrested during the Great Terror in all the national operations and the decree 00447 operation combined. Therefore, the number of Poles arrested amounted to 84.4 to 88.0 percent of the total number arrested in the Polish national operations. If this same ratio holds for the other national operations, then diaspora nationalities made up 25.7 to 26.8 percent of total arrests (and a still higher percentage of executions) during the mass operations of the Great Terror, although these same nationalities represented only 1.6 percent of the overall Soviet population. ${ }^{266}$

${ }^{264}$ For the national operations, no quotas were provided for executions and incarceration as they were with decree 00447 , although all executions in both operations had to be ratified by central authorities (albeit in the most rote fashion). This is one possible reason for the higher execution rates in the national operations.

${ }^{265}$ Platonav and Stashkevich,pp. 78-79.

${ }^{266}$ Vsesoiuznaia perepis' naseleniia $1937 \mathrm{~g}$.(n. 246 above),pp. 83-84. The targeting of diaspora nationalities is also confirmed by some recent evidence from Leningrad oblast. Using the biographical information of the 7,750 individuals executed in Leningrad city and oblast in August, September, and October 1937, as listed in Leningradskii martirolog (n. 249 above) (the list is said to be almost comprehensive and so valid for statistical analysis), I calculated the percentage of each nationality relative to the percentage that would be expected based on their total representation in the population of Leningrad city and oblast. Although the national operations (except the Polish one, which began August 20) were just beginning and most executions would have been part of the decree 00447 operations, the diaspora nationalities were still disproportionately affected. The number of Poles executed was 2,204 percent of what would be expected based on their total representation in the population of Leningrad city and oblast. In other words, due exclusively to their ethnicity, Poles were 22.04 times more likely to be executed than non-Poles. For diaspora nationalities, the targeting was not yet so extreme: Finns 183 percent, Estonians 265 percent, Germans 245 percent, Latvians 161 percent. These figures would be much higher were the post-September 1937 executions included. Non-diaspora nationalities were mostly underrepresented: Russians 75 percent, Jews 50 percent, Tatars 19 percent. Ukrainians were slightly overrepresented at 137 percent and Belorussians highly overrepresented at 461 percent (second only to the Poles). I suspect this substantial Belorussian 
Mass ethnic cleansing and the national operations were unsurprisingly accompanied by decrees abolishing all national soviets and national schools of the stigmatized diaspora nationalities. ${ }^{267}$ These decrees allowed the party to articulate an internal non-public explanation for the nationalities terror. These national institutions were declared to have been "artificially created" (iskusstvenno sozdano); that is, they were not even historically justified. Moreover, as Malenkov argued, it was often not even the party who created them: "It has now been established that in numerous cases national raiony were created by the initiative of enemies of the people in order to ease the development of counter-revolutionary espionage and wrecking." ${ }^{268}$ Likewise, a delegate to the October 1937 TsK plenum stated: "The Poles, through their national fascist and Trotskyist agents, filled the border regions with their people (svoimi liud'mi), such that their person (svoi chelovek) became head of the kolkhoz, head of the village soviet, and so forth." ${ }^{269}$ Although expressed in the paranoid vocabulary of the Great Terror, these comments essentially express the following realization: we thought national Soviets would disarm nationalism, but they have strengthened it; we thought they would insure loyalty from our diaspora nationalities, but they have undermined it; we felt they would help project our influence abroad, but the exact opposite occurred.

Before drawing my final conclusions about the origins of Soviet ethnic cleansing, I should first strongly emphasize the important consequences of the previously unappreciated scope of the mass terror against diaspora nationali-

(and less substantial Ukrainian) overrepresentation is the result of two factors. First, many Belorussians (and a smaller number of Ukrainians) were Catholics, who in the 1920s declared themselves to be Poles and sent their children to Polish schools. Therefore, they were arrested in large numbers during the Polish operation. For instance, in Belorussia itself, Belorussians made up 47.3 percent of those arrested in the Polish operation (more than the Poles at 43.0 percent). They made up 14.2 percent of those arrested in the Polish operation statewide from September to November 1938, more than any other nationality except the Poles themselves (Ukrainians were next at 13.6 percent and Russians next at 8.8 percent). Second, Belorussia and Ukraine were home to the largest diaspora nationality populations, and therefore the NKVD was simply likely to be more active in those republics (the same would be true of Leningrad and the Far East). The published Gulag statistics for 1939 also show a substantial overrepresentation of diaspora nationalities and underrepresentation of indigenous nationalities. However, Ukrainians are slightly underrepresented and Belorussians only slightly overrepresented, which may reflect the higher execution rates of the Polish operation. J. Arch Getty, Gabor T. Rittersporn, and Viktor N. Zemskov, "Victims of the Soviet Penal System in the Pre-War Years: A First Approach on the Basis of Archival Evidence," American Historical Review 98 (October 1993): 1028.

${ }^{267}$ RTsKhIDNI 17/3/994 (11.12.37): 56/75, 56/76, 17/114/633 (01.12.37): 75/6,75/7. There was one major exception: the Volga German ASSR and German schools within that republic were not abolished.

${ }^{268}$ RTsKhIDNI 17/114/829 (01.12.37): 75/6, p. 122.

${ }^{269}$ RTsKhIDNI 17/2/627 (11-12.10.37): 55-56. 
ties for our understanding of the Great Terror. Approximately 800,000 individuals were arrested, deported, or executed in the ethnic cleansing and mass national operations from 1935 to 1938. This represents around one-third of the total political victims in that time period. ${ }^{270}$ That fact alone requires at least two revisions to our interpretations of the Great Terror. First, in terms of the origins of the Great Terror, in addition to elite political explanations that focus on Stalin and his circle, regional explanations that highlight tensions in centerperiphery relations, ideological explanations that emphasize the continuation of class-based terror (the "former kulaks" in decree 00447), and social explanations that focus on leadership panic over crime (the "criminals" in decree 00447), we must add the national or xenophobic explanation that I have outlined in this article. ${ }^{271}$ In other words, the origins of Soviet ethnic cleansing are an important part of the origins of the Great Terror.

Second, in terms of the course of the Great Terror, it is striking that the terror itself exemplified and, to some degree, completed the larger transition from a primary focus on class-based terror to a preponderant emphasis on ethnicbased terror, which would continue until Stalin's death. Based on extensive work in the central NKVD archives, Roginskii and Petrov conclude that, from January to February 1938 (i.e., six to seven months into the sixteen-month period of mass terror), the national operations eclipsed decree 00447 as the primary focus of NKVD activity. By the final months of the terror, they were virtually the exclusive focus. ${ }^{272}$ Indeed, with only minor exaggeration, one might say that by November 1938 the Great Terror had evolved into an ethnic terror.

\section{CONCLUSION}

I began this article with a puzzle: How did a state with no ambition to turn itself into a nation-state - indeed, with the exact opposite ambition - nevertheless become the site of large-scale ethnic cleansing? In fact, the Soviet turn toward ethnic cleansing in the 1930s was not even accompanied by a trend favoring

${ }^{270}$ This is a rough estimate. I do not have arrest figures for $1935-36$, or comprehensive deportation figures for 1937-38.

${ }^{271}$ On elite political explanations, see Robert Conquest, The Great Terror: A Reassessment (New York, 1990). On regional explanations, see J.Arch Getty, Origins of the Great Purges: The Soviet Communist Party Reconsidered, 1933-1938 (Cambridge, 1985). For a "class-based" explanation, see Sheila Fitzpatrick, The Russian Revolution (Oxford, 1994), pp. 163-70. For the social explanation based on crime, see David Shearer, "Crime and Social Disorder in Stalin's Russia: A Reassessment of the Great Retreat and the Origins of Mass Repression," Cahiers du monde russe 39 (1998): 119-48. This is, of course, not meant to be a complete catalog of factors leading to the terror.

${ }^{272}$ Petrov and Roginskii (n. 253 above), p. 30. 
assimilation, but rather by an increased emphasis on the distinct primordial essence of the Soviet Union's nationalities. ${ }^{273}$ My explanation has three major strands. First, the Soviet leadership was already committed to ethnic resettlement in the 1920s to promote ethnic consolidation and the formation of national territories. Lenin and Woodrow Wilson were the two great propagandists for the right of nations to self-determination. While Lenin and Stalin opposed the creation of a Russian nation-state, they accepted the principle of the nationstate and sought to create its basic essentials - a national territory, elite, language, and culture - for each Soviet ethnic minority. They were, if you will, international nationalists. There is, then, a direct line connecting Soviet ethnic consolidation projects in the 1920s and Soviet participation in and sponsorship of the internationally sanctioned "liberal" ethnic cleansing that accompanied the conclusion of World War II: the Soviet Union's own population exchanges with Poland and Czechoslovakia and the expulsion of the German minority from eastern Europe. ${ }^{274}$ These actions were not undertaken in the pursuit of Russification or the creation of a Russian nation-state; rather, they embodied Soviet sponsorship of the ethnic consolidation (through ethnic cleansing) of its future East European allies, particularly Poland and Czechoslovakia, as well as of its own republics of Ukraine, Belorussia, and Lithuania.

Second, popular ethnic hostility played a role in the origins of Soviet ethnic cleansing. Due to the coincidence of status and ethnic divisions with conflicts over land and territory, some of the most important diaspora nationalities (Koreans, Germans, Finns, Poles) became the targets of popular ethnic hostility. This hostility led to harsh treatment during collectivization, which helped provoke mass emigration movements. It led local Communists to stigmatize these groups. Here again there is a link to the spread of Soviet ethnic cleansing beyond diaspora nationalities during World War II to embrace several North Caucasus nationalities (Chechens, Ingush, Balkars, Karachai). These nationalities had been involved in the most severe popular ethnic conflict during the 1920s and 1930s (as well as, of course, in the Tsarist period). ${ }^{275}$

Third, and most importantly, the Soviet belief in the political salience of ethnicity, which was reflected in the government's entire policy of supporting national institutions, led to its adoption of the Piedmont Principle: the attempt

${ }^{273}$ Slezkine (n. 12 above); Martin, "An Affirmative Action Empire" (n. 13 above), pp. 944-60.

${ }^{274}$ On the liberal ideology of national self-determination and ethnic cleansing, see David Laitin, Ethnic Cleansing, Liberal Style, MacArthur Foundation Program in Transnational Security, Working Paper Series, no. 4 (Cambridge, 1995).

${ }^{275}$ This is not to argue that all nationalities that were the subject of popular ethnic hostility were deported even in the North Caucasus. Dagestan had been the site of much ethnic conflict but experienced no deportations, whereas Kalmykia had seen little ethnic conflict and nonetheless the Kalmyks were deported. 
to exploit cross-border ethnic ties to project influence abroad. However, the exaggerated Soviet fear of foreign capitalist influence and contaminationwhat I have called Soviet xenophobia - also made such cross-border ties potentially suspect. Once it became clear to the Soviet leadership that crossborder ethnic ties could not be exploited to undermine neighboring countries, but instead had the opposite potential, their response was ethnic cleansing of the Soviet borderlands and, ultimately, ethnic terror throughout the Soviet Union. Again, ethnic cleansing of nationalities with suspect cross-border ethnic ties away from the Soviet borderlands continued throughout the late Stalinist period with the removal of the Crimean Tatars, Greeks, Armenians, Bulgarians, Meskhetian Turks, Kurds, Iranians, and Khemshils from the Black Sea and Transcaucasian border regions. ${ }^{276}$

Diaspora nationalities have often been seen as disloyal and so as an impediment to nation building, and therefore have been subject to ethnic cleansing. However, the Soviet case is unusual since, as I have emphasized, Soviet xenophobia was an ideological rather than an ethnic concept. It took on an ethnic content only due to the Piedmont Principle's focus on cross-border ethnic ties which, given the Soviet Union's geography, were exclusively non-Russian. In the late 1930s, alongside ethnic cleansing and ethnic primordialism, there was also a revival of a rather virulent state-sponsored Russian nationalist rhetoric, a revival that in fact peaked at the height of the Great Terror. ${ }^{277}$ However, this Russian nationalism is best understood as an effect rather than a cause of Soviet xenophobia. The growing fear of non-Russian nationalism and disloyalty due to the greater resistance to collectivization and the ethnicization of Soviet xenophobia through the reversal of the Piedmont Principle led the Soviet government to identify the state to a greater extent with its Russian core.

However, this did not prevent even Russians from becoming an enemy nation under certain circumstances. The January 1938 Politburo decree targeted the following diaspora nationalities for terror: Poles, Latvians, Germans, Estonians, Finns, Greeks, Iranians, Chinese, Romanians, and Kharbintsy. ${ }^{278}$ In this context, Kharbintsy sounds like some exotic Eurasian ethnicity. In fact, Kharbin was a town in northern China where the headquarters of the ChineseManchurian railway were located. Until the mid-1930s, the railway was owned and operated by the Soviet Union. Kharbintsy, who were primarily ethnic Russians, were the railway workers. After the sale of the railway to Japan, many returned to the Soviet Union. For the Soviet leadership, although they were ethnic Russians, their cross-border ethnic ties to the Kharbintsy remaining in

\footnotetext{
${ }^{276}$ For evidence that these operations were considered "cleansing" of border regions, see Bugai, L. Beriia (n. 9 above), pp. 149-50, 163-85.

${ }^{277}$ Martin, "An Affirmative Action Empire," pp. 962-71.

${ }^{278}$ Tak eto bylo, vol. 1 (n. 228 above), p. 253.
} 
China turned them into the functional equivalent of a diaspora nationality. And so, despite their Russianness, they too became an enemy nation targeted as part of the national operations during the Great Terror. ${ }^{279}$ This seems convincing evidence that it was Soviet, not Russian, xenophobia that drove the practice of Soviet ethnic cleansing.

${ }^{279}$ In addition to the January 1938 Politburo resolution on the Kharbintsy, see the NKVD targeting the Kharbintsy (modeled after the Polish decree 00485), "Operativnyi prikaz NKVD SSSR No.00593, 20.09.37,” Memorial-Aspekt, no. 1 (July 1993), p. 2. 